\title{
Plant-Based Antimicrobial Studies - Methods and Approaches to Study the Interaction between Natural Products
}

Authors

Affiliations
Sandy van Vuuren ${ }^{1}$, Alvaro Viljoen ${ }^{2}$

1 Department of Pharmacy and Pharmacology, Faculty of Health Sciences, University of the Witwatersrand, Parktown, South Africa

${ }^{2}$ Department of Pharmaceutical Sciences, Tshwane University of Technology, Pretoria, South Africa

\section{Key words \\ - additive \\ - antagonistic \\ - synergistic \\ - interactions \\ - antimicrobial \\ - plant}

received October 5,2010

revised Dec. 9, 2010

accepted Dec. 16, 2010

\section{Bibliography}

Dol http://dx.doi.org/ 10.1055/s-0030-1250736

Published online January 31 , 2011

Planta Med 2011; 77 :

1168-1182 @ Georg Thieme Verlag KG Stuttgart · New York . ISSN 0032-0943

\section{Correspondence}

Prof. Sandy van Vuuren

Department of Pharmacy and Pharmacology

Faculty of Health Sciences

University of the Witwatersrand

7 York Road

Parktown 2193

South Africa

Phone: + 270117172157

Fax: + 270116424355

Sandy.vanvuuren@wits.ac.za

\section{Abstract \\ $\nabla$}

The therapeutic value of synergistic interactions has been known since antiquity, and many different cultural healing systems still rely on this principle in the belief that combination therapy may enhance efficacy. This paper intends to provide an overview, from an antimicrobial perspective, on the research undertaken and interactive principles involved in pharmacognosy studies. Methods used to determine antimicrobial interactions include basic combination studies, the sum of the fractional inhibitory concentration index ( $\Sigma$ FIC), isobole interpretations, and death kinetic (timekill) assays. The various interactions are discussed with reference to molecules, different plant parts or fractions, different plant species, and combinations with nonbotanical antimicrobial agents. It is recommended for future development in the field of phytosynergy that consideration should be given to the selection criteria for the two inhibitors. A more conservative approach should be adopted when classifying synergy. When examining interactions in plant-based studies, antagonis-

\section{Introduction}

$\nabla$

The therapeutic value of synergistic interactions has been known since antiquity, and many different cultural healing systems have relied on this principle in the belief that combination therapy may enhance efficacy. The ancient texts pertaining to Ayurveda and traditional Chinese herbal medicine describe formulas consisting of complex herbal mixtures which may contain several plantbased ingredients [1]. African traditional healers rarely rely on a single plant for therapeutic regimens but often combine various plant parts and different species in order to achieve optimal results. The fundamental principle of aromatherapy is the combination of highly complex different es- tic interactions should not be ignored. Combinations involving more than two test samples should be examined where applicable, and very importantly, the mechanism of action of synergistic interactions should be given precedence. It is encouraging to observe the upsurge in papers exploring the complex interactions of medicinal plants, and undoubtedly this will become increasingly important in our continued quest to understand the mechanism of action of phytotherapy. The scientific validation of efficacious antimicrobial combinations could lead to patentable entities making research in the field of phytosynergy not only academically rewarding but also commercially relevant.

\section{Abbreviations \\ $\nabla$}

CFU: $\quad$ colony forming units

FIC: fractional inhibitory concentration

GC-MS: gas chromatography coupled to mass spectrometry

MIC: minimum inhibitory concentration

sential oils to achieve a therapeutic effect. The historical use and application of polyherbals has been carried down through the centuries, and today allopathic medicine commonly uses the very same principles to combine various molecules in single or separate dosage forms which are administered concomitantly. Recently, the application of combination therapy has gained a wider acceptance, especially in the treatment of infectious diseases. The World Health Organization, for example, has urged pharmaceutical companies to stop promoting the use of artemisinin derivatives in monotherapy. Instead, artemisinin combination therapy should be encouraged not only because it has a cure rate of $95 \%$ against the malaria parasite (Plasmodium falciparum) but may also con- 
tribute to curb resistance. Multidrug therapy has become of paramount importance in the fight against multidrug resistant microbial strains. Without the current multidrug approach used to treat tuberculosis (isoniazid, rifampicin, pyrazinamide, and ethambutol), the mortality of infected patients could reach global epidemic proportions. Another renowned antimicrobial agent having a significant synergistic effect in combination is amoxicillin (a $\beta$-lactam antibiotic) and clavulanic acid. Clavulanic acid binds to $\beta$-lactamase producing microorganisms, which protects amoxicillin from $\beta$-lactamase attack, which in turn results in an extended spectrum of activity for amoxicillin.

The concept of antimicrobial synergy is based on the principle that, in combination, the formulation may enhance efficacy, reduce toxicity, decrease adverse side effects, increase bioavailability, lower the dose and reduce the advance of antimicrobial resistance [2-4]. New antimicrobial combination drugs which include natural product combinations have recently become a research priority. This approach has financial implications as reformulation of existing drugs or combinations may prove to be a more viable option, rather than developing a new drug which will require extensive clinical trials for verification. Furthermore, the ban imposed by the United States of America and European Union on the use of allopathic antimicrobials in livestock farming has led to the search for natural antimicrobial combinations that may impact positively on agricultural and livestock farming [4]. Even though the concept of interactive antimicrobial therapy is well practised in western medicine, and many anecdotal accounts of plants used in combination for the treatment of microbe-related infections are evident, the validation of this phenomenon in the field of pharmacognosy has been neglected. Medicinal plants offer a vast resource of natural compounds, and the exploration of the various levels of interaction that may exist include: constituents within a plant, interactions between different parts of a plant, between different plant species, or the interaction with non-plant-based antimicrobials. It is encouraging to observe that there has been a recent increase in the number of publications reporting on plant-based pharmacological interactions. The concept of synergistic principles from a pharmacological and/or phytotherapeutic perspective has been addressed in various reviews [5-8], but these have not specifically focused on the antimicrobial interactions. The literature on the proposed methods appears fragmented and often confusing, and several experimental designs have been proposed, which leaves the results inconclusive. This review intends to succinctly collate the available literature which has focused on interactive plant-based antimicrobial studies and to propose various methods and approaches which could be considered when embarking on research in this field.

\section{Experimental Approaches}

$\nabla$

The terminology defining the possible interactions that may occur are often subject to debate and interpretation [5,9-13], thus for the sake of this review, the associated terminology should be defined. The word "synergy" is derived from the Greek word "syn-ergo" meaning working together, and the resulting effect may be defined as a combination that is significantly greater than the sum of its parts. Synonyms used include "polyvalent activity" and "potentiation". An "additive" or "summative" effect occurs when substances added together will improve or increase efficacy. A "noninteractive", "indifferent" effect, or "zero interaction" reflects an expected linear response when two agents are combined and show neither an additive nor antagonistic effect. "Antagonism" is a phenomenon where two or more agents in combination have an overall effect which is less than the sum of their individual effects $[12,14,15]$. For simplification, the terms "synergism, additive, indifferent, and antagonism" will be used to describe the types of interactions.

There are a number of different methodologies that have been proposed to express antimicrobial interactions. Many of these methods such as Etests, time-kill, and checkerboard methods have been comparatively evaluated [16-19]. Congruency in results for the evaluation of antibiotic synergy against Acinetobacter baumannii obtained between the three methods (Etests, time-kill, and checkerboard) varied between 51-72\% [18]. Comparative results generated from the time-kill and checkerboard method presented only a $51 \%$ value of congruency. Lewis et al. [19] favoured the Etest where antimicrobials of fixed concentrations are impregnated on commercially available filter strips. This method, however, is not applicable for plant-based antimicrobial studies in which the test antimicrobial is not a commercially available sample at standard concentrations but an experimental plant sample whose preparation is dependent on the undergoing study. Various authors have expressed concern over the methods used to interpret synergy [5,11-13,20-23]. In an editorial published in the Journal of Antimicrobial Chemotherapy [10], the interpretation of interactive methods was debated and a more conservative analysis of synergistic interpretations encouraged (see section "The fractional inhibitory concentration index" for further discussions on this). Mathematical models and statistical approaches to validate antimicrobial interactions have been developed to allow for a more reliable and quantitative assessment of pharmacological interactions [24-27].

Considering plant-based antimicrobial studies, the use of different methodologies range from the most basic disc diffusion assays found in earlier ethnobotanical studies $[28,29]$, to more recent studies incorporating the sum of the fractional inhibitory concentration index ( $\mathrm{FIC}$ ) [30-33], time-kill methods [34-38], and isobologram studies [3,39-43].

\section{"Basic" combination studies}

The simplest form of determining synergy is by means of diffusion assays. Each independent test sample (A or B) is placed in a well or on a disc. The combination $(A+B)$ is placed on a separate disc and the inhibition zone of the combination comparatively examined with the independent test samples. Should the inhibition zone be larger in A + B than either A or B then synergistic interactions are noted. Should the inhibition zone be smaller in A + B than A or B independently, then antagonistic interactions are noted. Although simple, these assays are subject to many variables which may influence the results and should at the most be used as a qualitative guide only $[40,44,45]$.

Basic minimum inhibitory concentration (MIC) assays may also be used to determine interactions. The microdilution method is undertaken, and combinations are comparatively assessed by incorporating the inhibitors at selected concentrations and combinations $[46,47]$. This arrangement of combinations formed by multiple dilutions is referred to as the checkerboard method.

Some combination studies have incorporated impedimetric methods extrapolating synergy by comparing growth as determined by optical density readings of single entities and comparing these growth rates with that found when exposed to test substances in combination $[48,49]$. One drawback in using such a 
method is that the assessment of viability is not always accurate when relying on turbidometric readings.

\section{The sum of the fractional inhibitory concentration index $(\Sigma \mathrm{FIC})$}

An algebraic equation to determine synergy by means of the $\Sigma$ FIC is a widely accepted means of measuring interaction. The $\Sigma F I C$ is expressed as the interaction of two agents where the concentration of each test agent in combination is expressed as a fraction of the concentration that would produce the same effect when used independently [50]. The $\Sigma F I C$ is then calculated for each test sample independently as specified in the following equations:

FIC $^{(* i)}=\frac{\text { MIC (a) in combination with }(\mathrm{b})}{\text { MIC (a) independently }}$

FIC $^{(* i i)}=\frac{\text { MIC }(\mathrm{b}) \text { in combination with }(\mathrm{a})}{\text { MIC (b) independently }}$

The sum of the FIC or FIC index is thus calculated as:

$\Sigma \mathrm{FICI}=\mathrm{FIC}^{(* \mathrm{i})}+\mathrm{FIC}^{(* \mathrm{ii})}$.

This basic equation has remained constant since inception. However, the interpretation has evolved and varies from author to author. The interpretation of the $\Sigma F I C$ index as a numerical value is arbitrary, and the thresholds presented have stemmed from the need to critically assess interactions that are clinically significant [13]. The earlier interpretations by Berenbaum [50] were very broad taking into account synergistic interactions having $\Sigma$ FIC values below one, antagonistic interactions above one, and additive interactions narrowly focused on one. These interpretations make it easy to analyse isobolograms and have been used in many papers describing interactions. A more conservative approach in describing interactions was recommended by Odds [10], with interpretations described as synergistic $(\Sigma F I C \leq 0.5)$, antagonistic $(\Sigma \mathrm{FIC}>4.0)$, and noninteractive $(\Sigma \mathrm{FIC}>0.5-4.0)$. The conservative approach takes into account inherent variations when performing MIC doubling dilution assays. Unfortunately, the "no interaction" range is a very broad one and makes no allowance for additive interpretations. A number of recent reputable studies, mainly reported in ISI antimicrobial journals, have incorporated an "additive" range into the interpretation for better clarification of the data set $[4,5,13,19,42,51-55]$. In the critical review by Bell [13], the need to include a broader range to interpret pharmacological interactions was emphasised. Taking this into account, an additive range should be included, and it is suggested that the interpretation of either synergistic $(\Sigma$ FIC $\leq 0.5)$, additive $(\Sigma$ FIC $>0.5-1.0)$, noninteractive $\Sigma$ FIC $(>1.0-\leq 4.0)$, or antagonistic $\left(\sum\right.$ FIC $\left.>4.0\right)$ should be used when describing in vitro antimicrobial interactions. A summary of the interpretative values given for the $\mathrm{FIC}$ in accordance with the corresponding authors is given in Table 1. Irrespective of the variations in interpretation, most authors are in agreement that synergistic interactions should be considered only for $\Sigma$ FIC values 0.5 and lower.

Although using $\Sigma$ FIC calculations to determine interaction appears to be the simplest method, one needs to consider the limitations. The FIC method is based on the assumption that half the concentration will provide half the effect. However, this is not always the case, as two inhibitors may not always have identical dose responses [11]. The use of isobolograms which take into account combinations at various concentrations provide a more realistic means of measurement.
Table 1 Classification of the $\Sigma F I C$ in accordance with corresponding authors.

\begin{tabular}{|lllll}
\hline \multicolumn{2}{l}{ Interaction } & \multicolumn{3}{c}{ References } \\
Synergy & Additive & Indifference & Antagonism \\
\hline$\leq 0.7$ & $*$ & $*$ & $\geq 1.3$ & {$[133]$} \\
\hline$<1.0$ & 1.0 & $*$ & $>1.0$ & {$[50,134]$} \\
\hline$\leq 0.5$ & $>0.5-4.0$ & & $>4.0$ & {$[135]$} \\
\hline$\leq 0.5$ & 1.0 & $*$ & $\geq 2.0$ & {$[4]$} \\
$\leq 0.5$ & $>0.5-1.0$ & $>1.0-<2.0$ & $\geq 2.0$ & {$[14]$} \\
\hline$\leq 0.5$ & $*$ & $>0.5-\leq 4.0$ & $>4.0$ & {$[23]$} \\
\hline$\leq 0.5$ & $0.5-<1.0$ & $\geq 1.0-<4.0$ & $\geq 4.0$ & {$[19]$} \\
\hline$\leq 0.5$ & $*$ & $>0.5-4.0$ & $>4.0$ & {$[136]$} \\
\hline$\leq 0.5$ & $*$ & $>0.5-4.0$ & $>4.0$ & {$[10]$} \\
\hline$<0.5$ & $0.5-1.0$ & $\geq 1.0-4.0$ & $>4.0$ & {$[53]$} \\
\hline$<0.5$ & $0.5-\leq 1.0$ & $>1.1-\leq 4.0$ & $>4.0$ & {$[106]$} \\
\hline$\leq 0.5$ & $*$ & $>0.5-<4.0$ & $\geq 4.0$ & {$[137]$} \\
\hline$\leq 0.5$ & $>0.5-0.75$ & $0.76-2.0$ & $\geq 2.0$ & {$[138]$} \\
\hline$\leq 0.5$ & $>0.5-1.0$ & $>1.0-\leq 4.0$ & $>4.0$ & {$[42]$, van Vuuren } \\
& & & & and Viljoen (recom- \\
& & & & mended herein) \\
\hline
\end{tabular}

* Not given by author

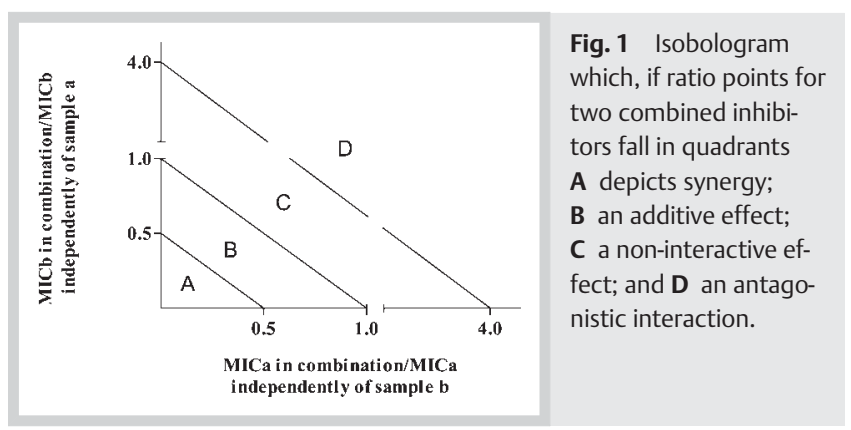

\section{The isobole method}

The isobole method of determining interaction is possibly one of the oldest methods used to express interactions, dating back to publications from 1870. Although well established, negative connotations have been associated with this method proving it unfavourable, until more recently when mathematical equations have been proposed to validate the results $[25,26]$. It is presently the favoured method for interactive assessment $[13,15]$. The principle is based on the fact that interactions may vary depending on the ratio in which the two inhibitors are combined. Although complicated, this method gives a more accurate assessment of each agent when studied in various combinations. The procedure involves the combination of two samples at various ratios. The MIC value for each sample is determined independently and comparatively assessed against the MIC value obtained in the ratio combination. This is expressed as a dose ratio response on an isobole graph. The adjoining line of the two axes indicates the individual doses and the isobologram can be interpreted by examining the data points of the ratios. The classical interpretation of the isobole is where the data points fall below the $1: 1$ line; synergy is expressed [50]. Antagonism is noted for data points falling above the $1: 1$ line, and an additive response is given when ratio points fall in the vicinity closest to or on the line. To standardise interactive values with the more conservative approach recommended by Odds [10], two additional lines are proposed, at the $0.5: 0.5$ and $4.0: 4.0$ axes ( $\bullet$ Fig. 1 ). These proposed 


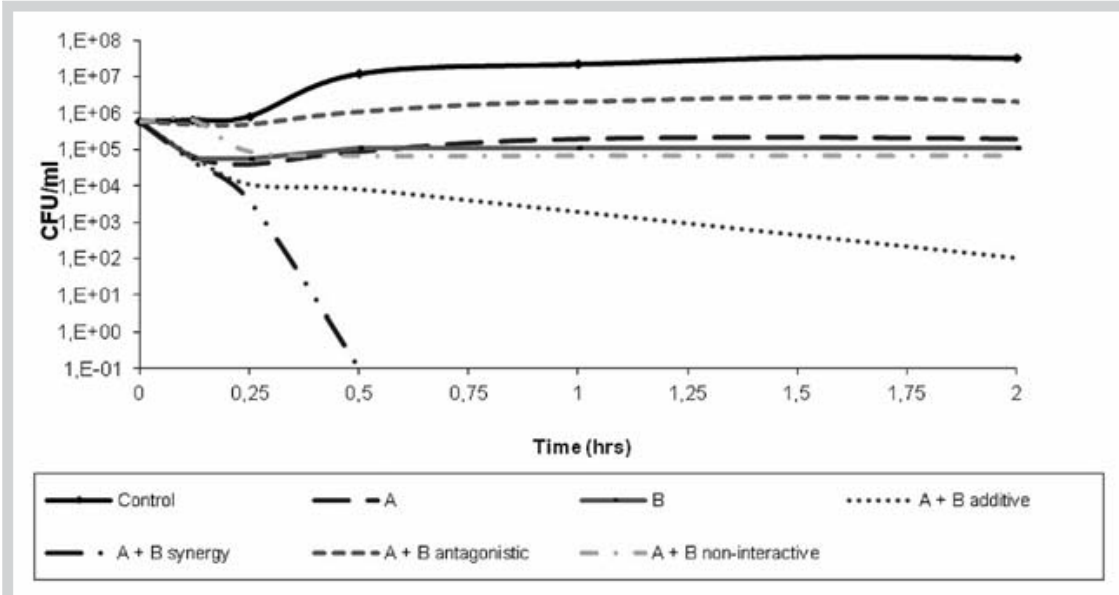

Fig. 2 Time-kill method of interpreting interactions when two samples are combined.

additions will allow cross comparison between $\Sigma$ FIC methods and isobole interpretations.

\section{Death kinetic (time-kill) assays}

Time-kill studies provide descriptive information on the relationship between bactericidal activity and the concentration of test substance [27]. Even though the methodology is labour intensive and requires a number of steps where variables may be introduced, valuable information is given of the death kinetics over time. The time-kill method has been praised as one of the best methodologies to study synergy [48], even though earlier shunned by Berenbaum [56]. Further validation of the death kinetic method to assess synergy was given [57], and the method was commended from a clinical perspective. In an overview of the various methods to test antimicrobial synergy with conventional antibiotics, the time-kill method was found to be one of the most frequently employed, showed better sensitivities and greater reproducibility [19]. Briefly, the principle involves exposing the inhibitor to a selected pathogen and, at selected time intervals, aliquots are sampled and serially diluted. The dilutions are plated out, incubated at optimum conditions for the test organism, and the colony forming units (CFU) are counted and plotted logarithmically against time. Depending on the curve of the dose response, either an additive, synergistic, or antagonistic effect is noted ( Fig. 2). Antagonism in time-kill methods may be defined as at least a100-fold increase in colony counts whereas synergism, a 100-fold decrease in colony counts [48].

In spite of the positive recommendation of this method to describe antimicrobial interactions, the method is not frequently used in plant-based studies. This is possibly due to the labourious nature of repetitive dilution sampling. The positive aspect of this method lies in the possibility to present a direct relationship in exposure of plant test material to a pathogen. A cidal effect is monitored over time which is not possible with the frequently used MIC assays.

\section{The Various Levels at Which Antimicrobial Interactions May Be Explored \\ $\nabla$}

\section{Interaction between molecules}

When examining the published literature and searching for scientific articles documenting the interactions between molecules, findings were predominantly focused on essential oil constitu- ents. A quick review of some of our own studies demonstrates varied essential oil compositions ranging anywhere from 25 to over 173 compounds in any given plant [40]. It is thus not surprising that any of these compounds may interact to either enhance or reduce pharmacological effects. With the sophisticated gas chromatography coupled to mass spectrometry (GC-MS) and the multidimensional gas chromatography techniques available today, detection of any number of compounds in a given plant may be undertaken. Investigation of these interactions has thus become a more viable option than isolating compounds from extracts and investigating interactions. Another limitation of isolating compounds and investigating their interactive properties is that yields are usually insufficient. With many essential oil studies, the identified compounds are done using commercially available databases and retention indices.

In a review on synergism by Harris [58], the author documents on a number of earlier antimicrobial studies (between 1974-1996) on volatile constituents that demonstrate synergistic interactions between constituents, synthetic substances, and even ingredients within a formulation. Pattnaik et al. [59] noted that MICs from essential oils were in many cases lower than the major constituents independently, suggesting that synergy between constituents may be contributing to the enhanced activity. In another study, linalool was combined with methyl charvicol at $\mathrm{v} / \mathrm{v}$ ratios of $1: 0 ; 0.8: 0.2 ; 0.6: 0.4 ; 0.4: 0.6 ; 0.2: 0.8$, and $0: 1$ [60]. It was observed that when these two monoterpene alcohols are combined, a higher efficacy is achieved, compared to when they are assayed independently. In another study, the interaction of the major essential oil constituents of four Thymus species was examined by the MIC checkerboard method [61]. Various interactions ranging from indifferent to synergistic were observed when combining carvacrol, thymol, 1,8-cineole, and p-cymene. No antagonism was noted, and the greatest synergistic interaction was observed with the thymol:1,8-cineole and thymol:p-cymene combination, having $\Sigma F I C$ values of 0.125 . In view of the international concern on the use of antibiotic growth promoters in animal feeds, it was interesting to note the application of combined essential oil constituents in controlling the antimicrobial populations in the pig gut. The combination of carvacrol and thymol demonstrated synergism, and recommendations for appropriate ratio studies to determine optimum synergistic effects were recommended [62].

In-depth isobologram interpretations have been undertaken on essential oil constituent interactions. Varied interactions were 
noted in a study where the pharmacological interactions of a number of essential oil constituents were investigated [63]. Synergism was observed between ( + )- $\beta$-pinene and carvacrol as well as between $\gamma$-terpinene and geranyl acetate when tested against Staphylococcus aureus. (+)- $\beta$-Pinene and (-)-menthone showed antagonism ( $\Sigma$ FIC value of 9.8 ), but interactions of $(+)-\beta$-pinene with 1,8-cineole demonstrated synergy ( $\Sigma \mathrm{FIC}$ value of 0.4 ), when tested together against Candida albicans. The combination of trans-geraniol and $E$ - and $Z$-( \pm )-nerolidol demonstrated an additive interaction against Bacillus cereus. For eugenol and $E$ - and $Z$ $( \pm)$-nerolidol, an indifferent interaction against Escherichia coli was noted. These results demonstrate varied interactions and not only synergism. All of these studies have one thing in common; they have focused on random essential oil constituent combinations.

Although there have been a number of papers that have focused on structure activity related antimicrobial studies of compounds within a plant [64-67], very little research has been conducted on how the co-occurrence of combined compounds contribute to efficacy. It has been questioned that independent activity related to one or two specific constituents is questionable and that synergistic functions between molecules are more probable [68]. In a study by Radulović [69], the major compound (68.6\% salicylaldehyde) from Filipendula vulgaris was isolated and found to be less active than the whole essential oil. When combined in a $60: 40$ ratio with linalool ( $1.8 \%$ composition in F. vulgaris oil), strong synergistic activity was noted. Interestingly, when salicylaldehyde was combined with another essential oil component, methyl salicylate $(2.4 \%)$ in a $60: 40$ ratio, antagonism was observed. We too have noted that synergistic interactions between molecules within a plant are evident. The two major essential oil components from Osmitopsis asteriscoides identified by GC-MS were (-)-camphor (12\%) and 1,8-cineole (60\%) representing $72 \%$ accumulatively. Time-kill studies were performed on the pathogen $C$. albicans, where (-)-camphor demonstrated negligible antimicrobial activity and 1,8-cineole indicated a cidal effect after $240 \mathrm{~min}$. When these two major compounds were tested in combination, a synergistic effect was noted having a cidal effect at $15 \mathrm{~min}$ [35]. Prediction that synergistic interactions occur only between major constituents may not always be accurate. Earlier studies demonstrated that less abundant components may interact synergistically [70]. This has been noted in other studies where the $\beta$-triketone complex of manuka oil was found to have poor bactericidal properties [34]. Similarly, we found this to be evident when investigating the antimicrobial activity of the major constituents of Artemisia afra. The four major compounds (artemisia ketone, 1,8-cineole, $\alpha$ and $\beta$-thujone, which accounts for $51.9 \%$ of the total composition) were investigated independently and in various permutations. Results showed minimal antimicrobial activity against Klebsiella pneumoniae. It was thus postulated that the minor compounds either independently or in combination contribute to the antimicrobial activity [37]. As noted in these interactions, when examining whole essential oils, predictions are complex and not only should major or minor compounds be considered, but one also needs to consider the stereochemistry of compounds. While it is known that biological activity is influenced by the enantiomeric configuration, the overall antimicrobial activity of different enantiomers may be additionally affected by interaction with other compounds. To demonstrate this, a study was undertaken on the different enantiomers of limonene in combination with 1,8-cineole. Isobologram plots for $S$. aureus demonstrated similar antagonis- tic activity when exposed to the combinations of 1,8-cineole with $(+)$ and $( \pm)$-limonene. However, with (-)-limonene, synergism was evident at selected ratios. Differences in activity were clearly noted with the other two pathogens studied (Pseudomonas aeruginosa and Cryptococcus neoformans), thus highlighting the significance of stereochemistry in antimicrobial combination studies.

Compound interaction studies on nonessential oil components include the combined effects of cinnamaldehyde with catechin, quercetin, or eugenol, tested against wood decay fungi with the aim to provide a rational in natural wood preservation. Varied interactions were noted ranging from synergistic to antagonistic when tested against the two fungal test organisms Lenzites betulina and Laetiporus sulphureus [71]. Another example where poorer antimicrobial activity is noted for the isolated compound rather than the combined compounds was reported in a study of linoleic and oleic acid, isolated from Helichrysum pedunculum, which were found to have higher activity against $S$. aureus and Micrococcus kristinae in combination (MIC value 0.05 ) than independently (MIC values 1.00) [72]. More recently [73], it was demonstrated that the biological effects observed for the major compounds of Ocimum gratissimum were not responsible for the overall effect of the essential oil. These types of studies reinforce the concept of a multi-targeted approach in therapeutic strategies and prove the hypothesis formulated by Tyler [74], that searching for potent antimicrobial compounds is becoming more and more improbable and that research should be moving towards the investigation of a combination of substances to achieve efficacy.

\section{Interactions between different plant parts or fractions}

Although it is evident that the many constituents within plants interact, it should also be noted that other interactions may occur between groups of molecules or fractions of the plant. For many species there is a strong distinction in the chemistry between the subterranean and above ground plant organs. If, for example, roots and leaves are combined, then the number of "active" compounds may be increased, and possibly an increased chance of synergistic interactions may occur. This may be why there are numerous anecdotal reports of plants used in combination therapy, i.e., when plant parts such as roots and leaves are combined and used in therapeutic regimens [75-79]. Even though the ethnobotanical use of many plants incorporates mixes of the different plant parts, there has been very little scientific evidence to support such interactive efficacies. There have been numerous screening studies that have investigated the antimicrobial activity of different plant parts such as fruit, leaf, root, barks, seeds, etc.; however, these have been investigated separately and not in combination [80-85]. Our studies on the various plant parts of Croton gratissimus was undertaken on the ethnopharmacological basis that these various parts are often used in combination. The root, leaf, and bark extracts were investigated singularly and combined in various ratios to establish possible interaction. The MIC value $(0.4 \mathrm{mg} / \mathrm{mL}), \Sigma F I C(0.4)$, and isobologram results (all ratios depicting synergy) for $C$. neoformans validate the traditional use of a root: leaf combination [41]. Up until recently, no other studies, other than our own work, could be found where different parts of the same plant are combined and investigated for antimicrobial efficacy $[41,86,87]$. It is encouraging to see such studies now being published, in which the individual and combined phenolics within the Olea europaea plant extract have been studied [88]. The results indicated that the combined phenolics had sig- 
nificantly higher antimicrobial activity than the individual phenolics investigated within the plant. Only one earlier study could be found that partially addresses the interactions that may occur between plant fractions. Garlic oil and allyl alcohol, both derived from Allium sativum, were combined and their interaction evaluated against Candida utilis. Isobolograms were used to interpret synergistic $\Sigma$ FIC values of between 0.37-0.42 [89].

Aromatic plants have an additional component of chemical complexity - the volatile constituents. In healing rituals, the volatiles may be administered selectively (inhalation) or the volatiles and nonvolatiles may by applied collectively, e.g., a poultice placed directly onto a wound or the alcoholic extraction (tincture) of crude plant material. It has been well recorded that extracts of aromatic plants have superior activity over the essential oils [41, $90,91]$. In our own studies, we explored the possible interaction between the volatile and nonvolatile fractions to yield greater antimicrobial activity. To test this hypothesis, a number of plants were investigated, i.e., three Pelargonium species (P. graveolens, $P$. quercifolium, P. tomentosum) [92], Plectranthus grandidentatus [40], three Salvia species (S. africana-caerulea, S. africana-lutea, and S. lanceolata) [86], and Tarchonanthus camphoratus [87]. These studies examined the need for coexistence of volatile and nonvolatile constituents to enhance antimicrobial efficacy. It is widely accepted that the administration of an infused oil may act as a penetrative enhancer [1], and possibly the synergistic interactions noted may be a result of improved solubility and bioactivity of the active principles.

\section{Interactions between different plant species}

Currently available on the market are phytomedicines which are sold as whole extract combinations, for example, Gingko biloba with Echinacea. It is believed that synergistic interactions are responsible for their therapeutic efficacy [15]. Many traditional healing practises prescribe plant combinations from different species to treat diseases. A comprehensive study has been undertaken on the ethnobotanical use of plant mixtures, in which 170 plant species from Cuba were examined for their combined medicinal use. Sixty-one combinations were attributed to anti-infective applications [93]. In African traditional medicine it is well known that traditional healers often combine various plant species in order to enhance efficacy. A number of instances where plants have been combined for the treatment of microbe related infections have been found in the ethnobotanical literature. Some documented accounts include the combination of Portulaca quadrifida with Monadenium lugardiae to treat stomach complaints, Trichilia emetica with Cyathula natalensis for leprosy, and Momoridica foetida with Pittosporum viridiflorum for boils. Various combinations of $C$. gratissimus have been used. Accounts of the administration with other species have been noted, e.g., for the treatment of swellings, the bark of $C$. gratissimus is combined with the root of Amaryllidaceae species and rubbed into incisions. Also noted is the use of the bark of $C$. gratissimus and Ocotea bullata in combination, which are powdered and blown into the womb to treat uterine disorders [76].

Given the fact that it is common traditional practice to combine medicinal plants, it was surprising to find so little published on plant to plant interactions. Previous studies include a study on the combination of Thymus vulgaris with Pimpinella anisum, two plants combined in Iraqi folk medicine. Both essential oils and methanol extracts were studied against nine test organisms, and predominantly additive interactions were noted [94]. Tea tree (Melaleuca alternifolia) and lavender (Lavandula angustifolia) es- sential oils were combined and tested against the dermatophytes Trichophytum rubrum and Trichophytum mentagrophytes var. interdigitale. Various combinations were prepared, and results presented in isobolograms, demonstrating an antimycotic effect [95].

Artemisia afra is one of the oldest and most widely used plants in African traditional medicine $[96,97]$. It is commonly used to treat respiratory infections such as coughs, colds, lung inflammation and often combined with plants such as Lippia javanica, Agathosma betulina, Osmitopsis asteriscoides, Eucalyptus globulus, Zanthoxylum capense, Leonotis microphylla, Tetradenia riparia, and Allium sativum $[75,76,98]$. In spite of these numerous reports in the ethnobotanical literature, very little research has been dedicated to validate these combinations. In our own combination studies on anti-infective African traditional medicines, A. afra was combined with $L$. javanica. The objective was to scientifically validate the concomitant use of these two coveted ethnomedicinals to treat respiratory infections. A time-kill assay was undertaken against the respiratory pathogen $K$. pneumoniae. Essential oil obtained from $L$. javanica $(0.25 \%)$ and $A$. afra $(0.25 \%)$ were run independently and in combination (L. javanica and A. afra together totalling $0.25 \%$ ). Artemisia afra when studied independently showed initial microbial destruction within one hour, but regrowth after $24 \mathrm{~h}$. For the L. javanica oil at $0.25 \%$, death kinetics was observed within $40 \mathrm{~min}$, but regrowth after four hours. When the two plants were combined, a bactericidal effect was maintained for the full 48 hours of testing. This synergistic effect scientifically validates the combined use of $L$. javanica and $A$. afra for the treatment of respiratory infections associated with $K$. pneumoniae and corroborates the traditional use of these two plants when administered in combination [40]. More recent results of the combination of the essential oils of $A$. afra with three medicinal aromatic plants, Agathosma betulina, Eucalyptus globulus, and 0 . asteriscoides, displayed predominantly additive interactions [99]. In an earlier combination study, we investigated the ethnobotanical use of Salvia chamelaeagnea in combination with Leonotis leonurus to treat respiratory infections. Individual extracts and a combination of the aerial parts of $S$. chamelaeagnea and $L$. leonurus were evaluated for the in vitro antibacterial activity ( FIC index presented as data points in isobolograms). When the two extracts were combined, synergistic actions were observed for the Gram-positive bacteria while antagonism, synergism, and/or additive actions were observed for the various ratios tested on studies with the Gram-negative bacteria [39].

Plant combinations with the potential to increase preservative efficacy in foods have recently been given more attention. The trend toward a more natural and greener approach to consumerism together with the economic benefit that may concur make this area of research attractive. Thus, a number of studies have been undertaken on food systems in the hope to achieve better antimicrobial effects in combination. A disc diffusion study was undertaken where Cinnamomum cassia was combined with $\mathrm{Al}$ lium tuberosum and the fruit of Cornus officinalis in a triple combination at varying ratios i.e., $1: 1: 1,8: 1: 1,6: 6: 1,1: 6: 6$, $1: 8: 1$, and $3: 1: 2$. The combination $8: 1: 1$ (C. officinalis: C. cassia: A. tuberosum) was found to possess antimicrobial efficacy against a wide range of test organisms. When applied to food systems, the combination retained antimicrobial activity [100]. Another interactive study with effective food preservation as an outcome was undertaken using isobolograms to interpret interactions. Fractions of Eucalyptus dives and Coriandrum sativum were combined and investigated against 12 test organisms. Of all the 
test organisms, Yersinia enterocolitica was the most susceptible to synergism. Other interactions varied between additive to antagonistic [101]. More recently, Origanum vulgare and Thymus vulgaris were combined and found to have an additive effect against food spoilage bacteria [102]. In another study, the interactive combination of cranberry, blueberry juice, and grape seed extract was antimicrobially tested against Helicobacter pylori. This study was undertaken on the assumption that a diet rich in phytocompounds may act prophylactically to ward off infection. Of the five different combinations formulated, the permutation having cranberry juice extract (75\%) with blueberry juice extract (10\%) and grape seed extract (15\%) demonstrated the highest synergy [103]. Multiple combination studies are challenging due to the endless number of permutations which exist to produce complex formulation. The development of predictive software using factorial designs to optimize experimental design may offer a solution to simplify the complexity.

A study on the combined effect of Origanum vulgare and Vaccinium macrocarpon was undertaken using the disc diffusion assay. Antimicrobial activity against Vibrio parahaemolyticus was best noted in a $1: 1$ combination [36]. Rosemary and clove essential oils have been combined and the antimicrobial efficacy reported using both MIC methods and time-kill studies. This comprehensive study was undertaken on a number of different pathogens and various MIC ratios depicted mostly additive effects against the test bacteria; Staphylococcus epidermidis, S. aureus, Bacillus subtilis, E. coli, Proteus vulgaris, and P. aeruginosa. The fungal test organisms, however, demonstrated either synergy (C. albicans) or antagonism (A. niger). The time-kill studies reported that combinations in lower concentrations were not sufficient to produce a cidal effect. Only concentrations twice that of the MIC value had a lethal effect [104]. Using synergistic principles, some plants were evaluated for the prevention of Cassava root rot during storage. Garlic, Landolphia owerrience, and Garcinia kola were investigated independently and in various 1:1 combinations. The combination of garlic with $G$. kola demonstrated the highest inhibition preventing rot during 14 days of storage [105]. Essential oil combinations of oregano (Origanum vulgare) with basil (Ocimum basilicum), lemon balm (Melissa officinalis), marjoram (Origanum majorana), rosemary (Rosmarinus officinalis), sage (Salvia trilo$b a$ ), and thyme (T. vulgaris) have been investigated against Bacillus cereus, Escherichia coli, Listeria monocytogenes, and Pseudomonas aeruginosa. All interactions either demonstrated an additive or indifferent effect in the MIC checkerboard method [106]. Using time-kill methods, a study was undertaken on Melaleuca alternifolia oil which was blended with a polar fraction of manuka (Leptospermum scoparium). Death kinetics demonstrated synergistic interactions [34]. Interactions between the isolated compound polygodial and plant species such as Perilla frutescens and Licaria puchuri-major have yielded varied results depending on the pathogen studied $[107,108]$. Another study focusing on selected unrelated compounds and the combination thereof was undertaken whereby the antimicrobial action of Staphylococcus aureus produced a synergistic effect when berberine, a common alkaloid found in a variety of plant species, was combined with 5'-methoxyhydnocarpin [109].

After reviewing the literature and examining the scientific interactive antimicrobial studies presented, it is clear that reports on antagonistic interactions seem to be largely ignored or possibly rejected by phytotherapy journals. It is thus encouraging to see that a study that focused on the antagonistic effects of two herbal extracts (Rhizoma Coptidis and Fructus Evodiae) in a traditional
Chinese medicine formula have recently been published. Findings suggest that the two samples have opposing effects [110].

\section{Antimicrobial plant interactions with nonbotanical antimicrobial agents}

Of all the interactions studied, research into phytoconstituents in combination with nonbotanical chemical entities has been the most widely studied. Studies range from plant interactions with preservatives to interactions with conventional antimicrobials. - Tables 2 and 3 record these studies including a summary with the salient outcomes achieved. Interactive interpretation is given according to the respective authors. For many of the plants whose allopathic combination studies were reviewed, either an additive or synergistic effect is presented. Very few reports have documented antagonism despite the fact that it is not unusual to encounter adverse drug reactions with herbal medicines [15]. In our own studies we assessed the interaction between a selection of popular commercial oils (Melaleuca alternifolia, Thymus vulgaris, Mentha piperita, and Rosmarinus officinalis) and conventional antimicrobials (ciprofloxacin and amphotericin B). The initial objective was to determine if a synergistic pattern predominates as noted in other similar studies reported in literature. Whilst some synergistic and additive interactions were evident between essential oils and antimicrobials, antagonistic interactions were also highlighted. It was interesting to note that when Melaleuca alternifolia (tea tree) oil which is often recommended for treatment of skin ailments, was combined with ciprofloxacin and tested against Staphylococcus aureus, antagonism was noted for all ratios in the isobologram [111]. This study highlights that caution should be adhered to when combining natural products with allopathic antimicrobials and addresses the proposal by Cuzzolin et al. [112], that there is a need for more systematic interactive studies to be undertaken to identify unfavourable combinations. Many of the methods employed to depict synergy between plants and nonbotanical components other than conventional antibiotics (Tables 2 and $\mathbf{3}$ ) are based on the experimental methods described herein. However, some studies have used alternate approaches to prove synergistic interactions. Such studies include the investigation of synergistic effects between catechin, an extract of green tea which was combined with ciprofloxacin using in vivo studies on a rat model. It was confirmed that the combination resulted in a statistically significant decrease in bacterial growth [113]. Kurita and Koike [114] examined the combination of ethanol, sodium chloride, or acetic acid with 19 essential oil components. Using an agar dilution method incorporating various combinations, the interactions were analysed over a 20-day period. Studies were undertaken with seven fungal species. Generally, a synergistic effect was noted when the variables were combined in pairs, threes, or altogether. In another study, synergistic interactions were also determined over a 21-day period against Penicillium notatum, however, with the incorporation of volatile compounds in an atmospheric jar. Synergistic interactions were noted for six combinations (ethanol: carvacrol; sulphur dioxide: carvacrol; sulphur dioxide: isothiocyanate; sulphur dioxide: cinnamaldehyde; isothiocyanate: cinnamaldehyde; cinnamaldehyde: carvacrol) [115]. A recent study demonstrated synergistic interactions with carvacrol. These combinations comprised of carvacrol with ciprofloxacin and carvacrol with amphotericin B against Bacillus cereus and C. albicans, respectively. Additionally, eugenol with ciprofloxacin or amphotericin B was synergistic when tested against $E$. coli and $C$. albicans, respectively [63]. 
Table 2 The combination of plants with conventional antibiotics.

\begin{tabular}{|c|c|c|c|c|}
\hline Plant derived test substance & $\begin{array}{l}\text { Non-plant derived } \\
\text { test substance }\end{array}$ & Test organism & Interaction & $\begin{array}{l}\text { Refer- } \\
\text { ences }\end{array}$ \\
\hline Santolina chamaecyparissus & clotrimazole & Candida albicans & synergistic when comparing MIC data & [139] \\
\hline $\begin{array}{l}\text { Agastache rugosa and major compound } \\
\text { estragole }\end{array}$ & ketoconazole & Blastoschizomyces capitatus & isobologram depicting synergy & [140] \\
\hline Bidwillon isolated from Erythrina variegata & mupirocin & Staphylococcus aureus & FIC values range between $0.5-1$ & {$[30]$} \\
\hline \multirow[t]{5}{*}{ Pomegranate extract } & chloramphenicol & \multirow[t]{5}{*}{ Staphylococcus aureus } & FIC values range between $0.03-1$ & \multirow[t]{5}{*}[31]{} \\
\hline & gentamicin & & FIC values range between $0.13-4$ & \\
\hline & ampicillin & & FIC values range between $0.03-1$ & \\
\hline & tetracycline & & FIC values range between $0.03-1$ & \\
\hline & oxacillin & & FIC values range between $0.03-1$ & \\
\hline \multirow{4}{*}{$\begin{array}{l}\text { Mentha piperita essential oil } \\
\text { and menthol }\end{array}$} & ampicillin & \multirow[t]{4}{*}{ Escherichia coli } & FIC values range between $1-2$ & \multirow[t]{4}{*}[53]{} \\
\hline & erythromycin & & $\mathrm{FIC}$ values range between $1-2$ & \\
\hline & gentamicin & & FIC values range between $1-1.25$ & \\
\hline & oxytetracycline & & FIC values of 0.5 & \\
\hline \multirow[t]{3}{*}{ Kola nitida } & ciprofloxacin & \multirow[t]{3}{*}{ Escherichia coli } & \multirow[t]{3}{*}{ potentiation for all antibiotics tested } & \multirow[t]{3}{*}[141]{} \\
\hline & pefloxacin & & & \\
\hline & levofloxacin & & & \\
\hline Cassia fistula fruit solution & amoxycillin & Salmonella enterica (48 isolates) & $\begin{array}{l}\text { FIC method indicated synergism for } 80 \% \\
\text { strains tested; no antagonism noted }\end{array}$ & {$[142]$} \\
\hline \multirow{2}{*}{$\begin{array}{l}\text { Essential oils from Cedrus atlantica, } \\
\text { Styrax tonkinensis, Juniperus communis, } \\
\text { Lavandula angustifolia, Melaleuca alternifolia, } \\
\text { Pelargonium graveolens, Pogestemon } \\
\text { patchouli, and Rosmarinus officinalis }\end{array}$} & ketoconazole & Aspergillus niger & \multirow[t]{2}{*}{$\mathrm{FIC}$ indices ranging from $0.52-1$} & \multirow[t]{2}{*}{ [143] } \\
\hline & amphotericin B & Aspergillus flavus & & \\
\hline \multirow{4}{*}{$\begin{array}{l}\text { Pelargonium graveolens and main } \\
\text { constituents citronellol, geraniol, } \\
\text { triacetin }\end{array}$} & \multirow[t]{4}{*}{ norfloxacin } & Bacillus subtilis & $\mathrm{FIC}$ indice 0.5 & \multirow[t]{4}{*}{ [144] } \\
\hline & & Bacillus cereus & $\begin{array}{l}\mathrm{FIC} \text { indices } 0.5 \text {; synergy in isobole } \\
\text { method for plant oil and norfloxacin }\end{array}$ & \\
\hline & & Staphylococcus aureus (2 strains) & $\begin{array}{l}\text { FIC indices ranging from } 0.37-0.5 \text {; } \\
\text { synergy in isobole method for plant oil } \\
\text { and norfloxacin }\end{array}$ & \\
\hline & & Escherichia coli & FIC indice 0.57 & \\
\hline Allium species (essential oils) & ketoconazole & Trichophytum spp. & $\mathrm{FIC}$ indices ranging from $0.09-0.75$ & [145] \\
\hline \multirow{2}{*}{$\begin{array}{l}\alpha \text {-Mangostin isolated from } \\
\text { Garcinia mangostana }\end{array}$} & ampicillin & Enterococcus faecalis (8 strains) & FIC values range between $0.5-1$ & \multirow[t]{2}{*}{ [146] } \\
\hline & gentamicin & Staphylococcus aureus (9 strains) & & \\
\hline \multirow[t]{3}{*}{ Catha edulis } & tetracycline & Streptococcus oralis & 4-fold potentiation & \multirow[t]{3}{*}[147]{} \\
\hline & tetracycline & Streptococcus sanguis & 2-fold potentiation & \\
\hline & penicillin G & Fusobacterium nucleatum & 4-fold potentiation & \\
\hline \multirow[t]{4}{*}{ Eight Chinese medicinal plants } & penicillin G & $\begin{array}{l}\text { resistant and standard strains of } \\
\text { Staphylococcus aureus }\end{array}$ & $\begin{array}{l}\% \text { inhibition of combination varies between } \\
<1 \text { (synergistic) to } 75.4\end{array}$ & [148] \\
\hline & gentamicin & & $\begin{array}{l}\% \text { inhibition of combination varies between } \\
<1 \text { (synergistic) to } 104.5\end{array}$ & \\
\hline & ciprofloxacin & & $\begin{array}{l}\text { \% inhibition of combination varies between } \\
<1 \text { (synergistic) to } 107.3\end{array}$ & \\
\hline & ceftriaxone & & $\begin{array}{l}\text { \% inhibition of combination varies between } \\
<1 \text { (synergistic) to } 71.5\end{array}$ & \\
\hline $\begin{array}{l}\text { Sophoraflavanone G isolated } \\
\text { from Sophora flavescens }\end{array}$ & gentamicin & 11 strains of oral bacteria & FIC values range between $0.28-0.75$ & [149] \\
\hline 15 traditional Indian plants & $\begin{array}{l}\text { tetracycline } \\
\text { ciprofloxacin }\end{array}$ & $\begin{array}{l}\text { Staphylococcus aureus } \\
\text { and Escherichia coli }\end{array}$ & $\begin{array}{l}\text { synergism or "neutralism" when } \\
\text { investigating inhibition zones }\end{array}$ & [150] \\
\hline $\begin{array}{l}\text { Melaleuca alternifolia, Origanum vulgare, } \\
\text { and Pelargonium graveolens }\end{array}$ & amphotericin B & 5 different Candida strains & $\begin{array}{l}\text { isobolograms demonstrating } \\
\text { P. graveolens oil with amphotericin B } \\
\text { as the most synergistic combination }\end{array}$ & [151] \\
\hline Galangin isolated from Alpinia officinarum & gentamycin & Staphylococcus aureus & FIC values range between $0.18-0.255$ & {$[32]$} \\
\hline Thymus eigii & $\begin{array}{l}\text { vancomycin } \\
\text { and erytromycin }\end{array}$ & 13 test organisms & antagonism determined by zone inhibition & [152] \\
\hline \multirow[t]{2}{*}{$\begin{array}{l}\text { Rhus coriaria, Psidium guajava, Lawsonia } \\
\text { inermis, Sacrpoterium spinosum }\end{array}$} & $\begin{array}{l}\text { oxytetracyclin } \\
\text { gentamicin }\end{array}$ & Staphylococcus aureus & $\begin{array}{l}\text { synergy determined by zone inhibition } \\
\text { synergy/antagonism determined by zone } \\
\text { inhibition }\end{array}$ & \multirow[t]{2}{*}{ [153] } \\
\hline & $\begin{array}{l}\text { enrofloxacin } \\
\text { sulphadimethoxin }\end{array}$ & & $\begin{array}{l}\text { antagonism determined by zone inhibition } \\
\text { synergy determined by zone inhibition }\end{array}$ & \\
\hline $\begin{array}{l}\text { Melaleuca alternifolia, Thymus vulgaris, } \\
\text { Mentha piperita, and Rosmarinus officinalis } \\
\text { essential oils }\end{array}$ & $\begin{array}{l}\text { ciprofloxacin and } \\
\text { amphotericin }\end{array}$ & $\begin{array}{l}\text { Staphylococcus aureus, } \\
\text { Klebsiella pneumoniae, } \\
\text { and Candida albicans }\end{array}$ & $\begin{array}{l}\text { antagonism mainly noted with } \\
\text { amphotericin B: essential oil combination }\end{array}$ & [111] \\
\hline
\end{tabular}


Table 2 The combination of plants with conventional antibiotics. (continued)

\begin{tabular}{|c|c|c|c|c|}
\hline Plant derived test substance & $\begin{array}{l}\text { Non-plant derived } \\
\text { test substance }\end{array}$ & Test organism & Interaction & $\begin{array}{l}\text { Refer- } \\
\text { ences }\end{array}$ \\
\hline Croton zehntneri & $\begin{array}{l}\text { gentamicin and } \\
\text { tetracycline }\end{array}$ & $\begin{array}{l}\text { Staphylococcus aureus and } \\
\text { Pseudomonas aeruginosa }\end{array}$ & $\begin{array}{l}\text { activity increased by } 42.8 \% \text { against } \\
\text { P. aeruginosa in combination }\end{array}$ & [154] \\
\hline Thespesia populnea & oxytetracycline & 12 bacterial strains & $\begin{array}{l}\text { highest synergy noted for Shigella boydii } \\
\text { using the disc diffusion method }\end{array}$ & [155] \\
\hline $\begin{array}{l}\text { Origanum vulgare, } \\
\text { Pelargonium graveolens, and } \\
\text { Melaleuca alternifolia }\end{array}$ & nystatin & 5 different Candida strains & $\begin{array}{l}\text { O. vulgare essential oil and nystatin } \\
\text { indicate most prominent synergy with } \\
\text { FIC indices between } 0.11 \text { and } 0.17\end{array}$ & [156] \\
\hline $\begin{array}{l}\text { Rhus coriaria, Sacropoterium spinosum, } \\
\text { Rosa damascene }\end{array}$ & $\begin{array}{l}\text { oxytetracycline, } \\
\text { penicillin G, cephalexin, } \\
\text { sulfadimethoxine and } \\
\text { enrofloxacine }\end{array}$ & $\begin{array}{l}\text { Pseudomonas aeruginosa } \\
\text { (3 clinical strains) }\end{array}$ & synergy & [157] \\
\hline Ocimum sanctum essential oil & $\begin{array}{l}\text { fluconazole and } \\
\text { ketoconazole }\end{array}$ & $\begin{array}{l}16 \text { fluconazole-resistant } \\
\text { Candida isolates }\end{array}$ & $\begin{array}{l}\text { FIC values ranging from mostly synergistic } \\
(0.25-0.50) \text { to indifferent }(0.52-0.93)\end{array}$ & [158] \\
\hline Melaleuca alternifolia oil & tobramycin & $\begin{array}{l}\text { Escherichia coli and } \\
\text { Staphylococcus aureus }\end{array}$ & $\begin{array}{l}\text { synergy demonstrated with time-kill } \\
\text { methods }\end{array}$ & [159] \\
\hline $\begin{array}{l}\text { Punicalagin isolated from } \\
\text { Punica granatum }\end{array}$ & fluconazole & Candida albicans & $\begin{array}{l}\text { synergy demonstrated with disc } \\
\text { diffusion, MIC, and time-kill methods }\end{array}$ & {$[160]$} \\
\hline $\begin{array}{l}\text { Eugenol, thymol, carvacrol, } \\
\text { cinnamaldehyde, allyl, and } \\
\text { isothiocyanate }\end{array}$ & $\begin{array}{l}\text { tetracycline, ampicillin, } \\
\text { penicillin G, erythromycin, } \\
\text { bacitracin, and novobiocin }\end{array}$ & $\begin{array}{l}\text { Salmonella typhimurium, } \\
\text { Escherichia coli, Streptococcus } \\
\text { pyogenes and Staphylococcus aureus }\end{array}$ & $\begin{array}{l}\text { FIC indices mostly indicating synergy } \\
\text { with strongest synergy noted (FIC } 0.11 \text { ) } \\
\text { with carvacrol: penicillin G combination } \\
\text { against } S \text {. aureus }\end{array}$ & [161] \\
\hline Myrtus communis essential oil & amphotericin B & $\begin{array}{l}\text { Candida albicans and } \\
\text { Aspergillus niger }\end{array}$ & $\begin{array}{l}\text { FIC indices and isobologram indicate } \\
\text { synergy }\end{array}$ & [162] \\
\hline $\begin{array}{l}\text { Thymus maroccanus and } \\
\text { Thymus broussonetii }\end{array}$ & $\begin{array}{l}\text { amphotericin B and } \\
\text { fluconazol }\end{array}$ & Candida albicans & $\begin{array}{l}\text { synergistic FIC indices ranging between } \\
0.27-0.49\end{array}$ & [163] \\
\hline
\end{tabular}

An area that has been sorely neglected is the incorporation of botanicals within formulations to achieve an enhanced naturally subsidised pharmaceutical product. Nostro et al. [116] examined the synergistic interactions of Calamintha officinalis with EDTA in cream formulations. More recently, Artemisia afra, Eucalyptus globulus, and Melaleuca alternifolia were encapsulated into diastearoyl phosphatidylcholine and diastearoyl phosphatidylethanolamine liposomes. The $\Sigma$ FICs were calculated in order to determine if the incorporation of essential oils would enhance the antimicrobial activity of the formulation. Synergistic to additive interactions were noted for encapsulated E. globulus ( $\Sigma$ FIC values $0.25-0.45$ ) and M. alternifolia ( FIC values $0.26-0.52$ ) formulations [33].

\section{Future Considerations}

$\nabla$

The reductionist approach in studying natural products For decades, phytochemists have been isolating natural products in the hope to find an antimicrobially active molecule comparable in activity to the allopathic antimicrobials available today. Yet, no single plant-derived antibacterial has been commercialised [117]. Perhaps this reductionist approach which limits complexity and variability is somewhat short-sighted when we consider the convolution of plants and the many compounds (major and minor) that may contribute to the overall activity of the plant. Allopathic medicine has realised the importance of studying the interaction between molecules for several years. Typical titles would include papers such as "In vitro synergy studies based on tazobactam/piperacillin against clinical isolates of metallo- $\beta$-lactamase-producing Pseudomonas aeruginosa" [118] and "Synergic activity, for anaerobes, of trovafloxacin with clindamycin or metronidazole: chequerboard and time-kill meth- ods" [119]. - Fig. 3 shows the number of papers reporting on pharmacological interactions for three journals (two plant based and one antimicrobial) over a ten-year period. The Journal of Antimicrobial Chemotherapy has consistently published a number of papers on this subject over the ten-year period (a total of 161). Ironically, the Journal of Ethnopharmacology and Planta Medica only carried 61 and six papers, respectively, over the same period. This is ironic for several reasons. The very nature of ethnopharmacology is based on traditional healing practices where crude extracts are administered, not molecules, and hence one cannot ignore the possible interactions between the various constituents and different species. Furthermore, researchers working in the field of ethnopharmacology often justify their projects based on traditional practices, but often the methodology followed is divorced from the real-life application in a traditional setting. Although it remains a rewarding and challenging exercise to search for the active principles in complex crude mixtures, it is not surprising that so many papers following this reductionist approach conclude that "the crude extract was more active than the isolated molecules".

\section{Natural products and antimicrobial mode of action}

The mode of action of conventional antimicrobials, both independently and in combination therapy, have been extensively studied. The mechanisms by which agents act on the cell wall interfere with biological pathways, and other more complex interactions have also been explored [57]. With respect to natural product combinations, the mechanism of synergy may be attributed to complex multi-target effects, pharmacokinetic or physiochemical properties, neutralization principles, or even therapeutic approaches [121]. Gilbert and Alves [120] have hypothesised on the efficacy of whole plant extracts rather than isolated molecules. Furthermore, an extensive review on possible modes of ac- 
Table 3 The combination of plants with nonbotanical agents other than conventional antibiotics.

\begin{tabular}{|c|c|c|c|c|}
\hline Plant derived test substance & $\begin{array}{l}\text { Non-plant derived } \\
\text { test substance }\end{array}$ & Test organism & Interaction & $\begin{array}{l}\text { Refer- } \\
\text { ence }\end{array}$ \\
\hline $\begin{array}{l}\text { Origanum vulgare and } \\
\text { Vaccinium macrocarpon }\end{array}$ & lactic acid & Vibrio parahaemolyticus & $\begin{array}{l}\text { total time-kill inhibition throughout } \\
10 \mathrm{~h} \text { tested }\end{array}$ & [36] \\
\hline Ocimum basilicum (anise variety) & $5 \% \mathrm{NaCl}$ & Lactobacillus curvatus & synergy using indirect impedance method & {$[60]$} \\
\hline \multirow[t]{4}{*}{ Thymol } & \multirow[t]{8}{*}{ potassium sorbate } & Escherichia coli & FIC values range between $0.5-1.1$ & \multirow[t]{8}{*}[52]{} \\
\hline & & Listeria innocua & FIC values range between $0.3-0.8$ & \\
\hline & & Salmonella typhimurium & $\mathrm{FIC}$ values range between $0.5-1.0$ & \\
\hline & & Staphylococcus aureus & FIC values range between $0.3-0.8$ & \\
\hline \multirow[t]{4}{*}{ Carvacrol } & & Escherichia coli & FIC values range between $0.5-0.8$ & \\
\hline & & Listeria innocua & FIC values range between $0.4-0.8$ & \\
\hline & & Salmonella typhimurium & FIC values range between $0.4-0.6$ & \\
\hline & & Staphylococcus aureus & FIC values range between $0.4-0.9$ & \\
\hline Rosmarinus officinalis & butylated hydroxyanisole & $\begin{array}{l}\text { Escherichia coli and Staphylococ- } \\
\text { cus aureus }\end{array}$ & $\begin{array}{l}\text { synergy for most points depicted on } \\
\text { the isobolograms }\end{array}$ & [43] \\
\hline Oregano \& oregano: cranberry extracts & sodium lactate (1-2\%) & Listeria moncytogenes & $\begin{array}{l}\text { total time-kill inhibition between days } \\
10-15\end{array}$ & [38] \\
\hline \multirow[t]{2}{*}{ Carvacrol, thymol, and eugenol } & nisin & Listeria moncytogenes & $\begin{array}{l}\text { optical density readings indicate reduction } \\
\text { in growth }\end{array}$ & [123] \\
\hline & diglycerol fatty acid esters & & $\begin{array}{l}\text { varied interaction depending on } \\
\text { compound studied }\end{array}$ & \\
\hline $\begin{array}{l}\text { Melaleuca alternifolia, Leptospermum } \\
\text { scoparium, and Leptospermum morrisonii }\end{array}$ & chlorhexidine digluconate & $\begin{array}{l}\text { Streptococcus mutans and Lacto- } \\
\text { bacillus plantarum }\end{array}$ & $\begin{array}{l}\text { CFU reduction 4-to } 10 \text {-fold depending } \\
\text { on the combination }\end{array}$ & [126] \\
\hline Thymol, carvacrol, citral, eugenol, geraniol & $\begin{array}{l}\text { acetic, citric, lactic, } \\
\text { and pyropolyphos- } \\
\text { phoric acids }\end{array}$ & Salmonella typhimurium & no synergistic effects noted & [164] \\
\hline Oils of fennel, anise, and basil & $\begin{array}{l}\text { benzoic acid and } \\
\text { methyl-paraben }\end{array}$ & $\begin{array}{l}\text { Listeria monocytogenes and Sal- } \\
\text { monella enteriditis }\end{array}$ & $\begin{array}{l}\text { synergy detected in five of the } 16 \\
\text { combinations studied }\end{array}$ & [165] \\
\hline $\begin{array}{l}\text { Thymus vulgaris, Rosmarinus officinalis, } \\
\text { Origanum vulgare }\end{array}$ & lactic acid & Listeria monocytogenes & $\begin{array}{l}\text { synergy at lower concentrations with } \\
\text { highest synergistic activity noted for } \\
\text { thyme: lactic acid and rosemary: lactic acid } \\
\text { combinations }\end{array}$ & [166] \\
\hline Eucalyptus oil, tea tree oil, and thymol & chlorhexidine digluconate & Staphylococcus epidermidis & $\begin{array}{l}\text { thymol: chlorhexidine digluconate } \\
\text { combination demonstrated the most } \\
\text { synergistic interactions with FIC values } \\
\text { of } 0.25\end{array}$ & [127] \\
\hline Nine different plant essential oils & enterocin AS-48 & Listeria monocytogenes & reduction in CFU for combinations & [167] \\
\hline Origanum vulgare subsp. hirtum & nisin & Salmonella enteriditis & $\begin{array}{l}\text { combination of } O \text {. vulgare essential oil at } \\
0.9 \% \text { and nisin at } 1000 \mathrm{IU} / \mathrm{g} \text { demonstrated } \\
\text { the best synergistic activity over time }\end{array}$ & [168] \\
\hline
\end{tabular}

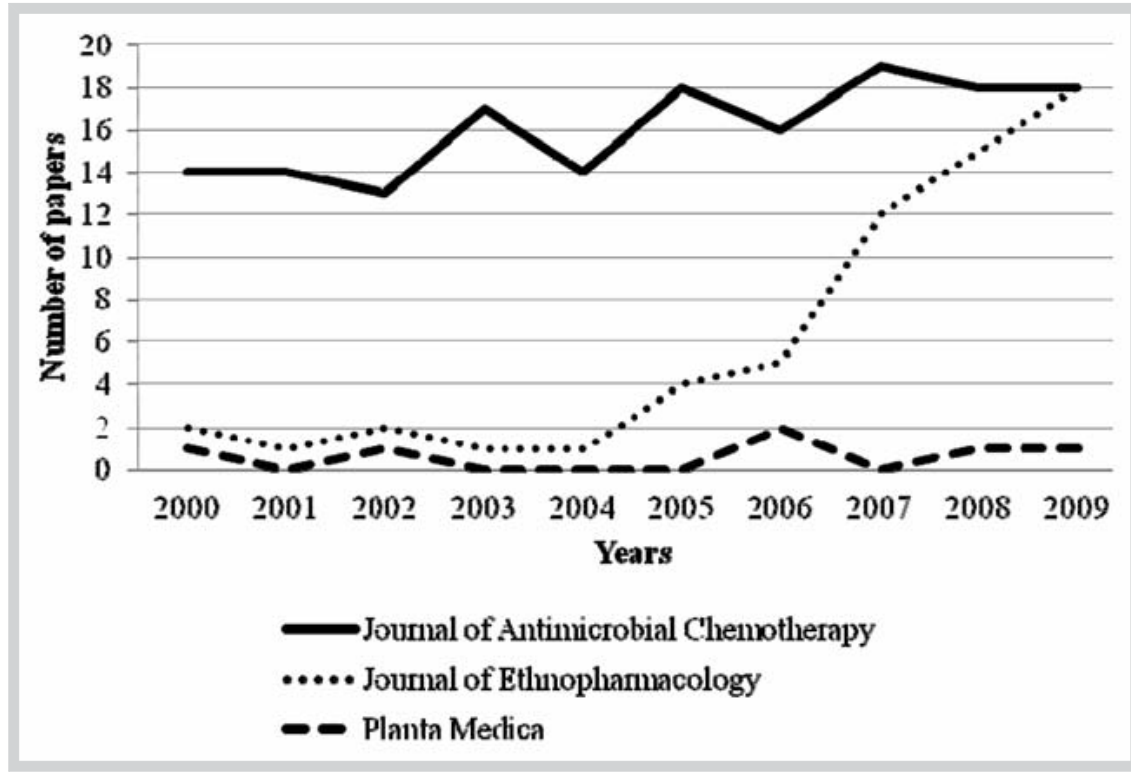

Fig. 3 Number of papers reporting on pharmacological interactions for three journals (Journal of Antimicrobial Chemotherapy, Journal of Ethnopharmacology, and Planta Medica) over a ten-year period. 
tion of natural products with allopathic antimicrobials has been undertaken [122]. Targets include receptor site modification, enzymatic degradation, reduced accumulation of drug within the bacterial cell, decreased membrane permeability, and efflux pumps. Even though these possible modes of action have been addressed, supporting studies to confirm these mechanisms are sorely lacking, especially with respect to combination therapy. When reviewing the literature on phytotherapeutic combinations, the elucidation of mode of action for both inhibitors are rarely reported in spite of the authors' efforts to include this as recommendations for further study $[52,101,123,124]$. In a study on the synergistic interaction of Punica granatum (methanol extract) with a range of antibiotics, the authors allude to the mode of action whereby the extract plays a role in efflux inhibition enhancing the uptake of a conventional drug [31]. In another study on the combination of an isoflavanone from Erythrina variegate with mupirocin, the mechanism of action is thought to involve bacterial cell membranes; however, further studies are recommended for confirmation [30]. One notable study that focused on mode of action with respect to combined inhibitors was the investigation of berberine with $5^{\prime}$-methoxyhydnocarpin where the mode of action was attributed to the effect of 5'-methoxyhydnocarpin blocking the Nor A pump and thus potentiating the antibiotic action of berberine [109]. This valuable insight into specific modes of action should be encouraged in future endeavours, keeping in mind that exploring this area of research may be extremely complex. One needs to consider the variability of possible interactions that may occur within this phytochemical pool, not only within a single extract but in various combinations. Furthermore, predominant mechanisms of action may be potentiated by other less effective modes of action [7] and vice versa.

\section{Biofilm inhibition from combined phytomedicinals}

Plant-based antimicrobial studies on planktonic microorganisms have been given extensive priority. The inhibition of biofilms, whether on independent or combined plant inhibitors, however, has been largely neglected. Combination studies are sparse, and the only interaction predominant in the literature is the combination of phytomedicinals with chlorhexidine digluconate, a skin antiseptic commonly used in clinical settings. Studies include the combined effect of Eucalyptus essential oil and the monoterpene 1,8-cineole with chlorhexidine digluconate, for which mainly synergistic interactions were found against C. albicans, E. coli, $P$. aeruginosa, $S$. aureus (including a methicillin resistant strain) biofilms [125]. Previous studies have shown that a number of essential oils together with chlorhexidine digluconate are effective in inhibiting biofilm cultures [126,127].

In another biofilm combination study, two diterpenoids, salvipisone and aethiopinone, isolated from the roots of Salvia sclarea and combined with beta-lactam antibiotics, demonstrated synergy. It was postulated that the mechanism of action may be due to cell surface hydrophobicity or cell wall permeability [128]. Studies such as this provide not only valuable information on biofilms but also offer explanations on possible modes of action.

\section{Conclusions}

$\nabla$

There has been a recent increase in awareness towards the concept of synergy within phytomedicine, as noted in a number of review style articles $[6,15,120,121]$. In conjunction with earlier publications on synergistic principles $[9,56,122,123,129,130]$, the validation of multiple phytotherapy has provided a much needed platform with which to expand future research in this area. In particular, research into antimicrobial combinations may yield new developments that may address the ever increasing concern towards antimicrobial resistance. It has been shown that resistance to crude extracts occurs less than resistance to single actives [131]. Thus, the search for single targeted molecules may not yield long-term solutions in combating antimicrobial resistance. For plants to rely on a single compound in their biochemical warfare with pathogens would be equivalent to relying on the "single golden bullet" approach, and thus, as researchers investigating the activity of single compounds, we would be ignoring the evolutionary approach that plants may have developed various metabolic mechanisms for the production of structurally and functionally diverse compounds to overcome emerging resistance. To ensure future success in natural product research, we encourage interactive phytochemical studies with existing practices in the hope that developments may be used as a foundation and driving force in the much needed discovery of novel chemotherapeutic agents.

It is recommended that future development in the field of phytosynergy should consider:

- The selection criteria for the two inhibitors. This should be clearly defined and justification should be given for the choice of test substances to be examined in combination.

- Classification of synergistic interactions should be more conservatively evaluated taking into account inherent doubling dilution variations noted in MIC methodology.

- Even though it is popular to report synergistic interactions, antagonism should be given the same priority.

- Combinations involving more than two plant entities should be examined where applicable.

- Combination studies involving biofilm inhibition should be considered.

- Articles addressing the mechanism of action of synergistic interactions should be given precedence. It is encouraging to note that some attention to this has been given $[6,120]$. The criteria addressed include receptor or site modification, enzymatic degradation, accumulation of antibiotic within bacterial cell, decreased outer membrane permeability, and efflux pumps. This area of research has been greatly neglected as many studies just report on the interactions that occur.

With such validations in place, the justification and development of antimicrobial combinations could lead to patentable entities making research in the field of phytosynergy commercially relevant [132]. New techniques, such as metabolomics and the dual applications of chemometric data analysis methods, are providing the researcher with new tools to explore this fascinating phenomenon which will undoubtedly become increasingly important in our continued quest to understand the mechanism of action of complex herbal preparations.

\section{References}

1 Shealy $C N$. The illustrated encyclopaedia of healing remedies. Australia: Element Books; 1998

2 Li RC, Schentag JJ, Nix DE. The fractional maximal effect method: a new way to characterize the effect of antibiotic combinations and other nonlinear pharmacodynamic interactions. Antimicrob Agents Chemother 1993; 37: 523-531

3 Inui T, Wang Y, Deng S, Smith DC, Franzblau SG, Pauli GF. Counter-current chromatography based analysis of synergy in an anti-tuberculosis ethnobotanical. J Chromatogr A 2007; 1151: 211-215

4 Cottarel G, Wierzbowski J. Combination drugs, an emerging option for antibacterial therapy. Trends Biotechnol 2007; 12: 547-555 
5 Chou T-C. Theoretical basis, experimental design, and computerized simulation of synergism and antagonism in drug combination studies. Pharmacol Rev 2006; 58: 623-642

6 Wagner $\mathrm{H}$. Multitarget therapy-the future of treatment for more than just functional dyspepsia. Phytomedicine 2006; 13: SV122-SV129

7 Biavatti MW. Synergy: an old wisdom, a new paradigm for pharmacotherapy. Braz J Pharm Sci 2009; 45: 371-378

$8 \mathrm{Ma} \mathrm{XH}$, Zheng CJ, Han LY, Xie B, Jia J, Cao ZW, Li YX, Chen YZ. Synergistic therapeutic actions of herbal ingredients and their mechanisms from molecular interaction and network perspectives. Drug Discov Today 2009; 14: 581-588

9 Berenbaum MC. What is synergy? Pharmacol Rev 1989; 41: 93-141

10 Odds FC. Synergy, antagonism, and what the chequerboard puts between them. J Antimicrob Chemother 2003; 52: 1-3

11 Lambert RJW, Lambert $R$. A model for the efficacy of combined inhibitors. J Appl Microbiol 2003; 95: 734-743

12 Johnson MD, MacDougall C, Ostrosky-Zeichner L, Perfect JR, Rex JH. Combination antifungal therapy. Antimicrob Agents Chemother 2004; 48: 693-715

13 Bell A. Antimalarial drug synergism and antagonism: mechanistic and clinical significance. FEMS Microbiol Lett 2005; 253: 171-184

14 ESCMID. Terminology relating to methods for the determination of susceptibility of bacteria to antimicrobial agents. The European Society of Clinical Microbiology and Infectious Diseases Eucast Definitive document E.Def 1.2. CMI 2000; 6: 503-515

15 Williamson EM. Synergy and other interactions in phytomedicines. Phytomedicine 2001; 8: 401-409

16 White RL, Burgess DS, Manduru M, Bosso JA. Comparison of three different in vitro methods of detecting synergy: time-kill, checkerboard and Etest. Antimicrob Agents Chemother 1996; 40: 1914-1918

$17 \mathrm{Wu} M$, Woolson RF. A comparison of several tests for drug synergy. Commun Statist Simula 1998; 27: 303-327

18 Bonapace CR, White RL, Friedrich LV, Basso JA. Evaluation of antibiotic synergy against Acinetobacter baumannii: a comparison with Etest, time-kill and checkerboard methods. Diagn Micro Infect Dis 2000; 38 : 43-50

19 Lewis RE, Diekema DJ, Messer SA, Pfaller MA, Klepser ME. Comparison of Etest, chequerboard dilution and time-kill studies for the detection of synergy or antagonism between antifungal agents tested against Candida species. J Antimicrob Chemother 2002; 49: 345-351

20 Ryan RW, Kwasnik I, Tilton RC. Methodological variation in antibiotic synergy test against enterococci. J Clin Microbiol 1981; 13: 73-75

21 Paull A, Marks J. A new method for the determination of bactericidal antibiotic synergy. J Antimicrob Chemother 1987; 20: 831-838

22 Rand KH, Houck HJ, Brown P, Bennett D. Reproducibility of the microdilution checkerboard method for antibiotic synergy. Antimicrob Agents Chemother 1993; 37: 613-615

23 Mackay ML, Milne K, Gould IM. Comparison of methods for assessing synergistic antibiotic interactions. Int J Antimicrob Agents 2000; 15: $125-129$

24 White DB, Faessel HM, Slocum HK, Khinkis L, Greco WR. Nonlinear response surface and mixture experiment methodologies applied to the study of synergism. Biom J 2004; 46: 56-71

25 Tallarida RJ. An overview of drug combination analysis with isobolograms. J Pharmacol Exp Ther 2006; 319: 1-7

26 Boucher AN, Tam VH. Mathematical formulation of additivity for antimicrobial agents. Diagn Micro Infect Dis 2006; 55: 319-325

27 Tam VH, Schilling AN, Nikolaou M. Modelling time-kill studies to discern the pharmacodynamics of meropenem. J Antimicrob Chemother 2005; 55: 699-706

28 Jain SR, Kar A. The antibacterial activity of some essential oils and their combinations. Planta Med 1971; 20: 118-123

29 Geda AK. Antibacterial activity of essential oils and their combinations. Fat Sci Technol 1995; 12: 458-460

30 Sato M, Tanaka H, Yamaguchi R, Kato K, Etoh H. Synergistic effects of mupirocin and an isoflavanone isolated from Erythrina variegata on growth and recovery of methicillin-resistant Staphylococcus aureus. Int J Antimicrob Agents 2004; 24: 241-246

31 Braga LC, Leite AAM, Xavier KGS, Takahashi JA, Bemquerer MP, ChartoneSouza E, Nascimento AMA. Synergistic interaction between pomegranate extract and antibiotics against Staphylococcus aureus. Can J Microbiol 2005; 51: 541-547

32 Lee YS, Kang OH, Choi JG, Oh YC, Chae HS, Kim JH, Park H, Sohn DH, Wang $Z-T$, Kwon DY. Synergistic effects of the combination of galangin with gentamicin against methicillin-resistant Staphylococcus aureus. J Microbiol 2008; 46: 283-288

33 Van Vuuren SF, du Toit LC, Parry A, Pillay V, Choonara YE. Encapsulation of essential oils within a polymeric liposomal formulation for enhancement of antimicrobial efficacy. Nat Prod Commun 2010; 5: 1401-1408

34 Christoph F, Stahl-Biskup E. Death kinetics of Staphylococcus aureus, exposed to commercial tea tree oils. J Essent Oil Res 2001; 13: 98-102

35 Viljoen AM, van Vuuren SF, Ernst E, Klepser M, Demirci B, Başer KHC, van Wyk BE. Osmitopsis asteriscoides (Asteraceae) - the antimicrobial activity and essential oil composition of a Cape-Dutch remedy. J Ethnopharmacol 2003; 88: 137-143

36 Lin YT, Labbe RG, Shetty K. Inhibition of Vibrio parahaemolyticus in seafood systems using oregano and cranberry phytochemical synergies and lactic acid. Innovat Food Sci Emerg Technol 2005; 6: 453-458

37 Viljoen AM, van Vuuren SF, Gwebu L, Demirci B, Baser KHC. The geographical variation and antimicrobial activity of African Wormwood (Artemisia afra Jacq.) essential oil. J Essent Oil Res 2006; 18: 19-25

38 Apostolidis E, Kwon YI, Shetty K. Inhibition of Listeria monocytogenes by oregano, cranberry and sodium lactate combination in broth and cooked ground beef systems and likely mode of action through proline metabolism. Int J Food Microbiol 2008; 128: 317-324

39 Kamatou GPP, Viljoen AM, van Vuuren SF. In vitro evidence of antimicrobial synergy between Salvia chamelaeagnea and Leonotis leonurus. S Afr J Bot 2006; 72: 634-636

40 Van Vuuren SF. The antimicrobial activity and essential oil composition of medicinal aromatic plants used in African traditional healing [PhD thesis]. South Africa: University of the Witwatersrand; 2007

41 Van Vuuren SF, Viljoen AM. In vitro evidence of phyto-synergy for plant part combinations of Croton gratissimus (Euphorbiaceae) used in African traditional healing. J Ethnopharmacol 2008; 119: 700-704

42 Iten F, Saller R, Abel G, Reichling J. Additive antimicrobial effects of the active components of the essential oil of Thymus vulgaris-chemotype carvacrol. Planta Med 2009; 75: 1-6

43 Romano C, Abadi K, Repetto V, Vojnov AA, Moreno S. Synergistic antioxidant and antibacterial activity of rosemary plus butylated derivatives. Food Chem 2009; 115: 456-461

44 Janssen AM, Scheffer JJC, Svendsen AB. Antimicrobial activity of essential oils: a 1976-1986 literature review. Aspects of the test methods. Planta Med 1987; 53: 395-398

45 Hewitt $W$, Vincent $S$. Theory and application of microbiological assay London: Academic Press (Inc.); 2003

46 Eloff JN. A sensitive and quick microplate method to determine the minimal inhibitory concentration of plant extracts for bacteria. Planta Med 1998; 64: 711-713

47 NCCLS. Methods for dilution antimicrobial susceptibility tests for bacteria, 6th edition. Wayne: Clinical and Laboratory Standards Institute; 2003

48 Beale AS, Sutherland R. Measurement of combined antibiotic action in antibiotics: Assessment of antimicrobial activity and resistance. London, UK: Academic Press (Inc.); 1983

49 Dufour M, Simmonds RS, Bremer PJ. Development of a method to quantify in vitro the synergistic activity of "natural" antimicrobials. Int J Food Microbiol 2003; 85: 249-258

50 Berenbaum MC. A method for testing for synergy with any number of agents. J Infect Dis 1978; 137: 122-130

51 Critchley IA, Sahm DF, Kelly LJ, Karlowsky JA. In vitro synergy studies using aztreonam and fluoroquinolone combinations against six species of Gram-negative bacilli. Chemotherapy 2003; 49: 44-48

52 Santiesteban-López A, Palou E, López-Malo A. Susceptibility of foodborne bacteria to binary combinations of antimicrobials at selected $\mathrm{a}(\mathrm{w})$ and pH. J Appl Microbiol 2007; 102: 486-497

53 Schelz Z, Molnar J, Hohmann J. Antimicrobial and antiplasmid activities of essential oils. Fitoterapia 2006; 77: 279-285

54 Netikul T, Leelaporn A, Leelarasmee A, Kiratisin P. In vitro activities of fosfomycin and carbapenem combinations against carbapenem nonsusceptible Escherichia coli and Klebsiella pneumoniae. Int J Antimicrob Agents 2010; 35: 609-610

55 De Oliveira CEV, Stamford TLM, Neto NJG, de Souza EL. Inhibition of Staphylococcus aureus in broth and meat broth using synergies of phenolics and organic acids. Int J Food Microbiol 2010; 137: 312-316

56 Berenbaum MC. Correlations between methods for measurements of synergy. J Infect Dis 1980; 142: 476-478

57 Acar JF. Antibiotic synergy and antagonism. Antibiotic therapy. Med Clin N Am 2000; 84: 1391-1406 
58 Harris $R$. Synergism in the essential oil world. Int J Aromather 2002; 12: $179-186$

59 Pattnaik S, Subramanyam VR, Bapaji M, Kole CR. Antibacterial and antifungal activity of aromatic constituents of essential oils. Microbiology 1997; 89: 39-46

60 Lachowicz KJ, Jones GP, Briggs DR, Bienvenu FE, Wan J, Wilcock A, Coventry $M J$. The synergistic preservative effects of the essential oils of sweet basil (Ocimum basilicum L.) against acid-tolerant food microflora. Lett Appl Microbiol 1998; 26: 209-214

61 Pina-Vaz C, Gonçalves Rodrigues A, Pinto E, Costa-de-Oliveira S, Tavares C, Salgueiro L, Cavaleiro C, Gonçalves MJ, Martinez-de-Oliveira J. Antifungal activity of Thymus oils and their major compounds. J Eur Acad Dermatol Venereol 2004; 18: 73-78

62 Michiels J, Missotten J, Fremaut D, De Smet S, Dierick N. In vitro dose-response of carvacrol, thymol, eugenol and trans-cinnamaldehyde and interaction of combinations for the antimicrobial activity against the pig gut flora. Livest Sci 2007; 109: 157-160

63 Van Zyl R, Seatlholo ST, van Vuuren SF, Viljoen AM. Pharmacological interactions of essential oil constituents on the viability of micro-organisms. Nat Prod Commun 2010; 5: 1381-1386

64 Tzakou O, Pitarokili D, Chinou IO, Harvala C. Composition and antimicrobial activity of the essential oil of Salvia ringens. Planta Med 2001; 67: $81-83$

65 Aggarwal KK, Khanuja SPS, Ahmad A, Kumar TRS, Gupta VK, Kumar S. Antimicrobial activity profiles of the two enantiomers of limonene and carvone isolated from the oils of Mentha spicata and Anethus sowa. Flavour Fragr J 2002; 17: 59-63

66 Setzer W, Vogler B, Schmidt J, Leahy J, Rives R. Antimicrobial activity of Artemisia douglasiana leaf essential oil. Fitoterapia 2004; 75: 192-200

67 Jirovetz L, Buchbauer G, Denkova Z, Stoyanova A, Murgov I, Schmidt E, Geissler M. Antimicrobial testings and gas chromatographic analysis of pure oxygenated monoterpenes 1,8-cineole, $\alpha$-terpineol, terpinin-4-ol and camphor as well as target compounds in essential oils of pine (Pinus pinaster), rosemary (Rosmarinus officinalis), tea tree (Melaleuca alternifolia). Sci Pharm 2005; 73: 27-39

68 Bakkali F, Averbeck S, Averbeck D, Idaomar M. Biological effects of essential oils - A review. Food Chem Toxicol 2008; 46: 446-475

69 Radulović N, Mišić M, Aleksić J, Doković D, Palić R, Stojanović G. Antimicrobial synergism and antagonism of salicylaldehyde in Filipendula vulgaris essential oil. Fitoterapia 2007; 78: 565-570

70 Chalchat JC, Garry R. Correlation between chemical composition and antimicrobial activity. VI. Activity of some African essential oils. J Essent Oil Res 1997; 9: 67-75

71 Yen $T-B$, Chang $S-T$. Synergistic effects of cinnamaldehyde in combination with eugenol against wood decay fungi. Bioresour Technol 2008; 99: 232-236

72 Dilika F, Bremner PD, Meyer JJM. Antibacterial activity of linoleic- and oleic acid isolated from Helichrysum pedunculatum, a plant used during circumcision rites. Fitoterapia 2000; 71: 450-452

73 Galindo LA, Pultrini AdM, Costa M. Biological effects of Ocimum gratissimum L. are due to synergic action among multiple compounds present in essential oil. J Nat Med 2010; 64: 436-441

74 Tyler VE. Phytomedicines: back to the future. J Nat Prod 1999; 62: 1589-1592

75 Watt JM, Breyer-Brandwijk MG. The medicinal and poisonous plants of southern and eastern Africa, 2nd edition. London, UK: Livingstone; 1962

76 Hutchings A, Scott AH, Lewis G, Cunningham AB. Zulu medicinal plants an inventory. Pietermaritzburg, South Africa: University of Natal Press; 1996

77 Van Wyk BE, van Oudtshoorn B, Gericke N. Medicinal plants of South Africa. Pretoria, South Africa: Briza; 1997

78 Von Koenen E. Medicinal poisonous and edible plants in Namibia. Windhoek, Namibia: Klaus Hess; 2001

79 Ngwenya MA, Koopman A, Williams R. Zulu botanical knowledge: An introduction. Durban, South Africa: National Botanical Institute; 2003

80 Caceres A, Alvarez AV, Ovando AE, Samayoa BE. Plants used in Guatemala for the treatment of respiratory diseases. Screening of 68 plants against gram-positive bacteria. J Ethnopharmacol 1991; 31: 193-208

81 Vlietinck AJ, van Hoof L, Totté J, Lasure A, van den Berghe D, Rwangabo PC, Mvukiyumwami J. Screening of hundred Rwandese medicinal plants for antimicrobial and antiviral properties. J Ethnopharmacol 1995; 46: 31-47

82 Rabe T, van Staden J. Antibacterial activity of South African plants used for medicinal purposes. J Ethnopharmacol 1997; 56: 81-87
83 Lin J, Opoku AR, Geheeb-Keller M, Hutchings AD, Terblanche SE, Jäger $A K$, van Staden J. Preliminary screening of some traditional Zulu medicinal plants for anti-inflammatory and anti-microbial activities. J Ethnopharmacol 1999; 68: 267-274

84 Drewes SE, Khan F, van Vuuren SF, Viljoen AM. Simple 1, 4-benzoquinones with antibacterial activity from stems and leaves of Gunnera perpensa. Phytochemistry 2005; 66: 1812-1816

85 Eldeen IMS, Elgorashi EE, van Staden J. Antibacterial, anti-inflammatory, anti-cholinesterase and mutagenic effects of extracts obtained from some trees used in South African traditional medicine. J Ethnopharmacol 2005; 102: 457-464

86 Kamatou GPP, van Zyl RL, Davids H, van Vuuren SF, Viljoen AM. Synergistic and antagonistic interactions of essential oils on the biological activities of the solvent extracts from three Salvia species. Nat Prod Commun 2008; 3: 1111-1115

87 Van Vuuren SF, Viljoen AM. Interaction between the non-volatile and volatile fractions on the antimicrobial activity of Tarchonanthus camphoratus. S Afr J Bot 2009; 75: 505-509

88 Lee $\mathrm{OH}$, Lee BY. Antioxidant and antimicrobial activities of individual and combined phenolics in Olea europaea leaf extract. Bioresour Technol 2010; 101: 3751-3754

89 Chung I, Kwon SH, Shim ST, Kyung KH. Synergistic anti-yeast activity of garlic oil and allyl alcohol derived from alliin in garlic. J Food Sci 2007; 72: 437-440

90 Van Vuuren SF, Viljoen AM, van Zyl RL, van Heerden FR, Baser KHC. The antimicrobial, antimalarial and toxicity profiles of helihumulone, leaf essential oil and extracts of Helichrysum cymosum (L.) D. Don subsp. cymosum. S Afr J Bot 2006; 72: 287-290

91 Van Vuuren SF. Antimicrobial activity of South African medicinal plants. J Ethnopharmacol 2008; 119: 462-472

92 Lalli JY, Viljoen AM, van Vuuren SF. Potential interaction between the volatile and non-volatile fractions on the in vitro antimicrobial activity of three South African Pelargonium (Geraniaceae) species. Nat Prod Commun 2010; 5: 1401-1408

93 Cano JH, Volpato G. Herbal mixtures in the traditional medicine of eastern Cuba. J Ethnopharmacol 2004; 90: 293-316

94 Al-Bayati FA. Synergistic antibacterial activity between Thymus vulgaris and Pimpinella anisum essential oils and methanol extracts. J Ethnopharmacol 2008; 116: 403-406

95 Cassella S, Cassella JP, Smith I. Synergistic antifungal activity of tea tree (Melaleuca alternifolia) and lavender (Lavandula angustifolia) essential oils against dermatophyte infection. Int J Aromather 2002; 12 : $2-14$

96 Thring TSA, Weitz FM. Medicinal plant use in the Bredasdorp/Elim region of the southern Overberg in the Western Cape Province of South Africa. J Ethnopharmacol 2006; 103: 261-275

97 Van Wyk BE. A broad review of commercially important southern African medicinal plants. J Ethnopharmacol 2008; 119: 342-355

98 Van Wyk BE, Gericke N. People's plants. A guide to useful plants of southern Africa, 1st edition. Pretoria, South Africa: Briza; 2000

99 Suliman S, van Vuuren SF, Viljoen AM. Validating antimicrobial combination therapy in African traditional medicines-a case for Artemisia afra. S Afr J Bot 2010; 76: 655-661

100 Hsieh PC, Mau JL, Huang SH. Antimicrobial effect of various combinations of plant extracts. Food Microbiol 2001; 18: 35-43

101 Delaquis PJ, Stanich K, Girard B, Mazza G. Antimicrobial activity of individual and mixed fractions of dill, cilantro, coriander and eucalyptus essential oils. Int J Food Microbiol 2002; 74: 101-109

102 Gutierrez J, Barry-Ryan C, Bourke P. Antimicrobial activity of plant essential oils using food model media: efficacy, synergistic potential and interactions with food components. Food Microbiol 2009; 26: $142-150$

103 Vattem DA, Lin YT, Ghaedian R, Shetty K. Cranberry synergies for dietary management of Helicobacter pylori infections. Process Biochem 2005; 40: 1583-1592

$104 \mathrm{Fu} Y J, \mathrm{Zu} Y$ Y, Chen LY, Shi XG, Wang Z, Sun S, Efferth T. Antimicrobia activity of clove and rosemary essential oils alone and in combination. Phytother Res 2007; 21: 989-994

105 Ubalua AO, Oti E. Evaluation of antimicrobial properties of some medicinal plants for fresh cassava roots preservation. Pakistan J Nutr 2008; 7: 679-681

106 Gutierrez J, Barry-Ryan C, Bourke P. The antimicrobial efficacy of plant essential oil combinations and interactions with food ingredients. Int J Food Microbiol 2008; 124: 91-97 
107 Kang R, Helms R, Stout MJ, Jaber H, Chen Z, Nakatzu T. Antimicrobial activity of the volatile constituents of Perilla frutescens and its synergistic effects with polygodial. J Agric Food Chem 1992; 40: 2328-2330

108 Himejima M, Kubo I. Antimicrobial agents from Licaria puchuri-major and their synergistic effect with polygodial. J Nat Prod 1992; 55: 620 625

109 Stermitz FR, Lorenz P, Tawara JN, Zenewicz LA, Lewis K. Synergy in a medicinal plant: antimicrobial action of berberine potentiated by $5^{\prime}-$ methoxyhydnocarpin, a multidrug pump inhibitor. Appl Biol Sci 2000; 97: 1433-1437

110 Zhao FR, Maoa HP, Zhang H, Hua LM, Wanga H, Wang YF, Yanagihara N, Gao XM. Antagonistic effects of two herbs in Zuojin Wan, a traditional Chinese medicine formula, oncatecholamine secretion in bovine adrenal medullary cells. Phytomedicine 2010; 17: 659-668

111 Van Vuuren SF, Suliman S, Viljoen AM. The antimicrobial activity of four commercial essential oils in combination with conventional antimicrobials. Lett Appl Microbiol 2009; 48: 440-446

112 Cuzzolin L, Zaffani S, Benoni G. Safety implications regarding use of phytomedicines. Eur J Clin Pharmacol 2006; 62: 37-42

113 Lee YS, Han CH, Kang SH, Lee S-J, Kim SW, Shin OR, Sim YC, Lee SJ, Cho $Y H$. Synergistic effect between catechin and ciprofloxacin on chronic bacterial prostatis rat model. Int J Urol 2005; 12: 383-389

114 Kurita N, Koike S. Synergistic antimicrobial effect of ethanol, sodium chloride, acetic acid and essential oil components. Agric Biol Chem 1983; 47: 67-75

115 Tunc S, Chollet E, Chalier P, Preziosi-Belloy L, Gontard N. Combined effect of volatile antimicrobial agents on the growth of Penicillium notatum. Int J Food Microbiol 2007; 113: 263-270

116 Nostro A, Cannatelli MA, Morelli I, Cioni PL, Bader A, Marino A, Alonzo V. Preservative properties of Calamintha officinalis essential oil with and without EDTA. Lett Appl Microbiol 2002; 35: 385-389

117 Gibbons S. Plants as a source of bacterial resistance modulators. Phytochem Rev 2005; 4: 63-78

118 Fujimura S, Takane H, Nakano Y, Watanabe A. In vitro synergy studies based on tazobactam/piperacillin against clinical isolates of metallobeta-lactamase-producing Pseudomonas aeruginosa. J Antimicrob Chemother 2009; 64: 1115-1116

119 Ednie LM, Credito KL, Khantipong M, Jacobs MR, Appelbaum PC. Synergic activity, for anaerobes, of trovafloxacin with clindamycin or metronidazole: chequerboard and time-kill methods. J Antimicrob Chemother 2000; 45: 633-638

120 Gilbert B, Alves LF. Synergy in plant medicines. Curr Med Chem 2003; 10: $13-20$

121 Wagner H, Ulrich-Merzenich G. Synergy research: approaching a new generation of phytopharmaceuticals. Phytomedicine 2009; 16: 97110

122 Hemaiswarya S, Kruthiventi AK, Doble M. Synergism between natural products and antibiotics against infectious diseases. Phytomedicine 2008; 15: 639-652

123 Yamazaki K, Yamamoto T, Kawai Y, Inoue N. Enhancement of antilisterial activity of essential oils constituents by nisin and diglycerol fatty acid ester. Food Microbiol 2004; 21: 283-289

124 Rios JL, Recio M. Medicinal plants and antimicrobial activity. J Ethnopharmacol 2005; 100: 80-84

125 Hendry ER, Worthington T, Conway BR, Lambert PA. Antimicrobial efficacy of eucalyptus oil and 1,8-cineole alone and in combination with chlorhexidine digluconate against microorganisms grown in planktonic and biofilm cultures. J Ethnopharmacol 2009; 64: 1219-1225

126 Filoche SK, Soma K, Sissons CH. Antimicrobial effects of essential oils in combination with chlorhexidine digluconate. Oral Microbiol Immun 2005; 20: 221-225

127 Karpanen TJ, Worthington T, Hendry ER, Conway BR, Lambert PA. Antimicrobial efficacy of chlorhexidine digluconate alone and in combination with eucalyptus oil, tea tree oil and thymol against planktonic and biofilm cultures of Staphylococcus epidermidis. J Ethnopharmacol 2008; 62: 1031-1036

128 Walencka E, Rozalska S, Wysokinska H, Rozalski M, Kuzma L, Rozalska $B$. Salvipisone and aethiopinone from Salvia sclarea hairy roots modulate staphylococcal antibiotic resistance and express anti-biofilm activity. Planta Med 2007; 73: 545-551

129 Berenbaum MC. The expected effect of a combination of agents: the general solution. J Theor Biol 1985; 114: 413-431
130 Greco WR, Bravo G, Parsons JC. The search for synergy: A critical review from a response surface perspective. Pharmacol Rev 1995; 47: 332-382

131 Burfield T, Reekie S-L. Mosquitoes, malaria and essential oils. Int J Aromather 2005; 15: 30-41

132 Lambert RJW, Johnston MD, Hanlon GW, Denyer SP. Theory of antimicrobial combinations: biocide mixtures - synergy or addition? J Appl Microbiol 2003; 94: 747-759

133 Kerry DW, Hamilton-Miller JMT, Brumfitt W. Trimethoprim and rifampicin: in vitro activities separately and in combination. J Antimicrob Chemother 1975; 1: 417-427

134 Norden CW, Wentzel H, Keleti E. Comparison of techniques for measurements of in vitro antibiotic synergism. J Infect Dis 1979; 140: 629-633

135 Eliopoulos GM, Moellering Jr RC. Antimicrobial combinations. Antibiotics in laboratory medicine, 3rd edition. Baltimore: Williams and Wilkins; 1991

136 Moody JA. Synergism testing: Broth microdilution checkerboard and broth microdilution. In: Isenberg HD, editor. Clinical microbiology procedures handbook, 1 st edition. Washington, DC. American Society for Microbiology 2003; 18: 1-28

137 Krishnan-Natesan S, Chandrasekar PH, Manavathu EK, Revankar SG. Successful treatment of primary cutaneous Aspergillus ustus infection with surgical debridement and a combination of voriconazole and terbinafine. Diagn Microbiol Infect Dis 2008; 62: 443-446

138 Goñi P, López P, Sánchez C, Gómez-Lus R, Becerril R, Nerín C. Antimicrobial activity in the vapour phase of a combination of cinnamon and clove essential oils. Food Chem 2009; 116: 982-989

139 Suresh B, Sriram S, Dhanaraj SA, Elango K, Chinnaswamy K. Anticandidal activity of Santolina chamaecyparissus volatile oil. J Ethnopharmacol 1997; 55: 151-159

140 Shin S, Kang CA. Antifungal activity of the essential oil of Agastache rugosa Kuntze and its synergism with ketoconazole. Lett Appl Microbiol 2003; 36: 111-115

141 Ibezim EC, Esimone CO, Nnamani PO, Onyishi IV, Brown SA, Obodo CE. In vitro study of the interaction between some fluoroquinolones and extracts of kola nitida seed. Afr J Biotechnol 2006; 5: 1781-1784

142 Ali NH, Kazmi SU, Faizi S. Activity of synergistic combination Amoxycassia against Salmonella. Pakistan J Pharm Sci 2007; 20: 140-145

143 Shin S. Anti-Aspergillus activities of plant essential oils and their combination effects with ketoconazole or amphotericin B. Arch Pharm Res 2003; 26: 389-393

144 Rosato A, Vitali C, De Laurentis N, Armenise D, Milillo MA. Antibacterial effect of some essential oils administered alone or in combination with norfloxacin. Phytomedicine 2007; 14: 727-732

145 Pyun MS, Shin S. Antifungal effects of the volatile oils from Allium plants against Trichophyton species and synergism of the oils with ketoconazole. Phytomedicine 2006; 13: 394-400

146 Sakagami Y, Iinuma M, Piyasena KG, Dharmaratne HR. Antibacterial activity of $\alpha$-mangostin against vancomycin resistant Enterococci (VRE) and synergism with antibiotics. Phytomedicine 2005; 12: 203-208

147 Al-hebshi N, Al-haroni M, Skaug N. In vitro antimicrobial and resistance-modifying activities of aqueous crude khat extracts against oral microorganisms. Arch Oral Biol 2006; 51: 183-188

148 Yang ZC, Wang BC, Yang XS, Wang $Q$, Ran L. The synergistic activity of antibiotics combined with eight traditional Chinese medicines against two different strains of Staphylococcus aureus. Colloids Surf B Biointerfaces 2005; 41: 79-81

149 Cha JD, Jeong MR, Jeong SI, Lee KY. Antibacterial activity of sophoraflavanone G isolated from the roots of Sophora flavescens. J Microbiol Biotechnol 2007; 17: 858-864

150 Ahmed I, Aqil F. In vitro efficacy of bioactive extracts of 15 medicinal plants against ES $\beta$ L-producing multidrug-resistant enteric bacteria. Microbial Res 2007; 162: 264-275

151 Rosato A, Vitali C, Gallo D, Balenzano L, Mallamaci R. The inhibition of Candida species by selected essential oils and their synergism with amphotericin B. Phytomedicine 2008; 15: 635-638

152 Toroglu S. In vitro antimicrobial activity and antagonistic effect of essential oils from plant species. J Environ Biol 2007; 28: 551-559

153 Adwan GM, Abu-shanab BA, Adwan KM. In vitro activity of certain drugs in combination with plant extracts against Staphylococcus aureus infections. Pakistan J Med Sci 2008; 24: 541-544 
154 Rodrigues FF, Costa JG, Coutinho HD. Synergy effects of the antibiotics gentamicin and the essential oil of Croton zehntneri. Phytomedicine 2009; 16: 1052-1055

155 Kumar AS, Venkateshwaran K, Vanitha J, Saravanan VS, Ganesh M, Vasudevan M, Sivakumar Bangladesh T. Synergistic activity of methanolic extract of Thespesia populnea. (Malvaceae) flowers with oxytetracycline. J Pharmacol 2009; 4: 13-16

156 Rosato A, Vitali C, Piarulli M, Mazzotta M, Argentieri MP, Mallamaci R. In vitro synergic efficacy of the combination of nystatin with the essential oils of Origanum vulgare and Pelargonium graveolens against some Candida species. Phytomedicine 2009; 16: 972-975

157 Adwan G, Abu-Shanab B, Adwan K. Antibacterial activities of some plant extracts alone and in combination with different antimicrobials against multidrug-resistant Pseudomonas aeruginosa strains. Asian Pacific J Trop Med 2010; 24: 266-269

158 Amber K, Aijaz A, Immaculata X, Luqman KA, Nikhat M. Anticandidal effect of Ocimum sanctum essential oil and its synergy with fluconazole and ketoconazole. Phytomedicine 2010; 17: 921-925

159 D’Arrigo MD, Ginestra G, Mandalari G, Furneri PM, Bisignano G. Synergism and postantibiotic effect of tobramycin and Melaleuca alternifolia (tea tree) oil against Staphylococcus aureus and Escherichia coli. Phytomedicine 2009; 17: 317-322

160 Endo EH, Cortez DAC, Ueda-Nakamura T, Nakamura CV, Filho BPD. Potent antifungal activity of extracts and pure compound isolated from pomegranate peels and synergism with fluconazole against Candida albicans. Res Microbiol, advance online publication 21 June 2010; doi: 10.1016/j.resmic.2010.05.002

161 Palaniappan K, Holley RA. Use of natural antimicrobials to increase antibiotic susceptibility of drug resistant bacteria. Int J Food Microbiol 2010; 140: 164-168
162 Mahboubi IM, Bidgoli FG. In vitro synergistic efficacy of combination of amphotericin B with Myrtus communis essential oil against clinical isolates of Candida albicans. Phytomedicine 2010; 17: 771-774

163 Saad A, Fadli M, Bouaziz M, Benharref A, Mezrioui N-E, Hassani L. Anticandidal activity of the essential oils of Thymus maroccanus and Thymus broussonetii and their synergism with amphotericin B and fluconazol. Phytomedicine, advance online publication 18 June 2010; doi: 10.1016/j.phymed.2010.03.020

164 Nazer AI, Kobilinsky A, Tholozan JL, Dubois-Brissonnet F. Combinations of food antimicrobials at low levels to inhibit the growth of Salmonella sv. typhimurium: a synergistic effect? Food Microbiol 2005; 22: 391398

165 Fyfe L, Armstrong F, Stewart J. Inhibition of Listeria monocytogenes and Salmonella enteriditis by combinations of plant oils and derivatives of benzoic acid: the development of synergistic antimicrobial combinations. Int J Antimicrob Agents 1998; 9: 195-199

166 Dimitrijević SI, Mihajlovski KR, Antonović DG, Milanović-Stevanović $M R$, Mijin DZ. A study of the synergistic antilisterial effects of a sublethal dose of lactic acid and essential oils from Thymus vulgaris L., Rosmarinus officinalis L. and Origanum vulgare L. Food Chem 2007; 104: 774-782

167 Molinos AC, Abriouel H, López RL, Omar NB, Valdivia E, Gálvez A. Enhanced bactericidal activity of enterocin AS-48 in combination with essential oils, natural bioactive compounds and chemical preservatives against Listeria monocytogenes in ready-to-eat salad. Food Chem Toxicol 2009; 47: 2216-2223

168 Govaris A, Solomakos N, Pexara A, Chatzopoulou PS. The antimicrobial effect of oregano essential oil, nisin and their combination against Salmonella enteritidis in minced sheep meat during refrigerated storage. Int J Food Microbiol 2010; 137: 175-180

Please note: This article was changed according to the following erratum in Planta Medica 2012: 78: 302: Reference 31 was changed. 